\title{
Revision and new species of the African genus Mischogyne (Annonaceae)
}

\author{
George Gosline ${ }^{1}$ (D), Andrew R. Marshall ${ }^{2,3,4}$ \& Isabel Larridon ${ }^{1,5}$
}

Summary. Mischogyne (Annonaceae, tribe Monodoreae) is a genus of small- to medium-sized tropical trees and shrubs. It is characterised by a combination of: (1) stamens and carpels on a more or less extended torus; (2) carpels divergent from each other at the apex of the torus above the anthers; (3) anthers linear and anther connectives not expanded above the thecae; (4) inflorescences extra-axillary (or sometimes terminal in M. michelioides) with usually solitary flowers; (5) petals reflexed at anthesis (except M. michelioides), and (6) prominent reticulate tertiary veins. The genus is found in the lowland tropical rainforests of Africa with annual precipitation of $1000-4000 \mathrm{~mm}$ and in the dry coastal foothills of Angola. Five species and one variety of Mischogyne are recognised. One newly discovered species from the Eastern Arc Mountains, M. iddii, is described. The variety M. elliotiana var. glabra is reduced into synonymy with M. elliotiana var. elliotiana. Mischogyne elliotiana var. gabonensis is raised to species level as M. gabonensis. Specimens from the Congo are recognised as a new species, M. congensis. Preliminary conservation status assessments are provided for each species, as well as an identification key and detailed species descriptions. An unusual distribution pattern for the genus is discussed: dry coastal Angola as well as West, Central and East African wet forest.

Key Words. Angola, Eastern Arc, IUCN - conservation, Monodoreae, taxonomy.

\section{Introduction}

The unexpected identification of a new species of Mischogyne Exell from the Eastern Arc Mountains of Tanzania led us to undertake a revision of this genus, previously considered to have just two species. This is a contribution to the body of revisions of African genera of Annonaceae which have been published in recent years: Duguetia A.St.-Hil. (Chatrou 1998), Isolona Engl. and Monodora Dunal (Couvreur 2009), Huberantha Chaowasku (in Chaowasku et al. 2015), Annickia Setten \& Maas (Versteegh \& Sosef 2007), Hexalobus A.DC. (Botermans et al. 2011), Neostenanthera Exell (Fero et al. 2014), Uvariastrum Engl. (Couvreur 2014), Piptostigma Oliv. and Brieya De Wild. (Ghogue et al. 2017), and new genera Mwasumbia Couvreur \& D.M.Johnson (in Couvreur et al. 2009) and Sirdavidia Couvreur \& Sauquet (Couvreur et al. 2015).

Mischogyne Exell belongs to the subfamily Annonoideae Raf. and tribe Monodoreae Baill. (Chatrou et al. 2012). This tribe contains eleven African genera whose phylogenetic relationships were studied by Couvreur et al. (2008a). Mischogyne resolves within the tribe as sister to the subclade including Uvariodendron (Engl. \& Diels) R.E.Fr., Monocyclanthus Keay, and Uvariopsis Engl.

Mischogyne is a genus of five species characterised by the combination of: (1) stamens and carpels on a more or less extended torus; (2) carpels divergent from each other at the apex of the torus above the anthers; (3) anthers linear and anther connectives not expanded above the thecae; (4) inflorescences extraaxillary (or sometimes terminal in $M$. michelioides) with usually solitary flowers; (5) petals reflexed at anthesis (except $M$ michelioides), and (6) prominent reticulate tertiary veins.

\section{Taxonomic History}

The genus Mischogyne was erected by Exell (1932) to accommodate Mischogyne michelioides Exell, first collected by Gossweiler in 1930. Exell (1932) noted in his description the elongate attenuate "androgynophore" that sets this species apart from any other genus of Annonaceae, and "gives to the flower a distinctly magnoliaceous aspect". He specu-

\footnotetext{
Accepted for publication 13 March 2019. Published online 2 July 2019

1 Royal Botanic Gardens, Kew, Richmond, Surrey, TW9 3AE, UK. e-mail: g.gosline@kew.org

2 University of the Sunshine Coast, Tropical Forests and People Research Centre, Sippy Downs, QLD 4556, Australia.

3 University of York, Environment Department, Heslington, York, YO10 5NG, UK.

4 Flamingo Land Ltd. Kirby Misperton, North Yorkshire YO17 6UX, UK.

${ }^{5}$ Ghent University, Department of Biology, Systematic and Evolutionary Botany Lab, K.L. Ledeganckstraat 35, 9000, Gent, Belgium.
} 
lated on the relationship to the Magnoliaceae, which turned out to be, as he also said, "no more than an extraordinary parallelism."

The genus was considered monotypic until 1952 when R. E. Fries circulated a preprint (the formal publication was Fries 1955) in which he proposed that the species Uvariastrum elliotianum (Engl. \& Diels) Sprague \& Hutch. was better placed in the genus Mischogyne (Fries 1955), now confirmed by molecular markers. Mischogyne elliotiana (Engl. \& Diels) Le Thomas has a cylindrical torus, but not nearly as prominent as the long-stalked one of M. michelioides. Fries (1955) noted the similar anthers lacking an extended connective. The two species share the strongly reticulate tertiary venation characteristic of Mischogyne although this was not mentioned by Fries. Turner (2013) noted that Fries' new combination failed to fully reference the place of publication of the basionym as required by the International Code of Nomenclature (Lanjouw 1952) which came into effect in 1953. Turner therefore credited Le Thomas (1969) with the first valid publication of the combination M. elliotianum and we incorporate this attribution. The basionym for the species was Uvaria elliotiana Engl. \& Diels (Engler 1901) and the epithet was correctly changed to the masculine by Sprague \& Hutchinson (1916) when they transferred the species to Uvariastrum. Unfortunately, Fries (1955) did not change the epithet to the feminine in his transfer to Mischogyne. Evrard (1967) corrected Keay's M. elliotianum var. glabrum to $M$. elliotianum var. glabra, but without correcting the species epithet. (Note that this change does not change the author according to article 32.2 of the ICN Turland et al. 2018) and that the citation Mischogyne elliotianum var. glabra (Keay) Evrard is incorrect). We make the gender correction here to Mischogyne elliotiana, and to the varietal epithets as well.

At about the same time, Keay (1952) published new taxa in preparation for the publication of the second edition of the Flora of West Tropical Africa. In examining the material of Uvariastrum elliotianum, he described two new varieties in addition to the typical species. He stated that they "have been noted in the MS [for the flora] as new species, but, I consider, are best treated as varieties." These are: (1) Uvariastrum elliotianum (Engl. \& Diels) Sprague \& Hutch. var. glabrum Keay, (2) Uvariastrum elliotianum (Engl. \& Diels) Sprague \& Hutch. var. sericeum Keay, and (3) the autonym Uvariastrum elliotianum (Engl. \& Diels) Sprague \& Hutch. var. elliotianum.

Finally, Le Thomas (1969) published a fourth variety based on a nomen nudum of Pellegrin (1949): Mischogyne elliotianum (Engl. \& Diels) R.E.Fries var. gabonensis Pellegr. ex Le Thomas.

\section{Materials and Methods}

\section{Morphology}

Measurements were made on dried herbarium specimens and on calibrated specimen images; characters such as shape and colour are based on field notes and photos. Plane shape description terminology is based on Systematics Association Committee for Descriptive Biological Terminology (1962); other terminology, including indumentum, is based on Beentje (2015). All known specimen records of Mischogyne were identified, georeferenced and examined and are listed in the supplement $\mathrm{S} 1$ of the paper. Specimens examined are listed in the relevant section of the species accounts ("!" indicates a specimen seen and "*” that a high-resolution image of the specimen was viewed). In addition to herbarium searches at $\mathrm{K}$ and BM, specimen records from GBIF and Chatelain et al. (2011) were evaluated and georeferenced. Specimen images were viewed using the portals for BR, L (WAG), LISC and P. Measurements of digital images were made using ImageJ (Schneider et al. 2012). In the case of the Ghana and Ivory Coast herbaria, label information is not available and the identifications and georeferencing are assumed to be correct in plotting species distributions. In all other cases georeferencing based on label data was done using GoogleEarth (https://www.google.com/intl/en_uk/ earth/desktop/) and online searches.

Photos (Couvreur and Jongkind) were accessed from the World Annonaceae website (Couvreur, T.L.P. and Annonaceae Community n.d http:// annonaceae.myspecies.info).

Preliminary conservation assessments for each species follow IUCN criteria (IUCN 2012) and are based on the distribution of herbarium specimens (Schatz 2002). We used the online tool GeoCAT (Bachman et al. 2011) to calculate Extent of Occurrence (EOO) and Area of Occupancy (AOO). AOO is calculated using a cell-size of $4 \mathrm{~km}^{2}$. The map was generated with ArcMap 10.1 (ESRI 2011).

\section{Molecular methods}

New sequences were generated for three chloroplast regions ( $r b c L$ gene, $t r n H-p s b A$ intergenic spacer (IGS), trnL intron and trnL-trnF IGS) from Mischogyne herbarium specimens representing three accepted species and two putative new species to science. This data was supplemented with previously published chloroplast sequence data (Couvreur et al. 2008a; Parmentier et al. 2013) from 16 species representing 10 related genera. Voucher information is provided in Table 1.

After tissue homogenisation (Mixer Mill, Retsch GmbH \& co., Haan, Germany), total DNA was extracted from $5-20 \mathrm{mg}$ of dried material using a modified cetyl trimethyl ammonium bromide (CTAB) protocol (Doyle \& Doyle 1990). The $r b c L$ gene was 
amplified using the primers $1 \mathrm{~F}$ and $724 \mathrm{R}$ or using the primers 636F (Fay et al. 1997) and 1460R (Fay et al. 1998 the $t r n H-p s b A$ IGS was amplified using primers trn $H^{(\mathrm{GUG})}$ and $p s b A$ (Hamilton 1999) and the universal primers C/D and E/F (Taberlet et al. 1991) were used to amplify the $t r n L$ intron and $t r n L-F$ spacer.

Amplifications were performed in volumes of $50 \mu \mathrm{l}$ containing a 2× PCR Premix 'DreamTaq' (4.0 mM $\mathrm{MgCl}_{2}$ ) (Thermo Fisher Scientific, Waltham, Massachusetts, USA), 5× TBT (Samarakoon et al. 2013) with primer solution with a concentration of $10 \mu \mathrm{M}$, and 1 $\mu \mathrm{L}$ of unquantified DNA.

Initial denaturation was set to $2 \mathrm{~min}$ at $94^{\circ} \mathrm{C}[\mathrm{rbcL}$ 1F-724R, trnL-F], to $3 \mathrm{~min}$ at $94^{\circ} \mathrm{C}$ [ rbcL 636F-1460R], and to $5 \mathrm{~min}$ at $96^{\circ} \mathrm{C}$ [trnH-psbA]. After this, polymerase chain reaction (PCR) was performed for 30 cycles (28 for $r b c L$ 636F-1460R, 35 for trnH-psbA) of denaturation $\left(1 \mathrm{~min}\right.$ at $94^{\circ} \mathrm{C}, 45 \mathrm{~s}$ at $96^{\circ} \mathrm{C}$ [trnH-psbA]), primer annealing for $1 \mathrm{~min}$ (at $48^{\circ} \mathrm{C}[\mathrm{rbcL}]$, at $53^{\circ} \mathrm{C}[\mathrm{trnH}-$ $p s b A]$, at $\left.50^{\circ} \mathrm{C}[t r n L-F]\right)$, and primer extension at $72^{\circ} \mathrm{C}$ (for $90 \mathrm{~s}$ [rbcL 1F-724R, trnL-F], $1 \mathrm{~min}$ [rbcL 636F1460R], $30 \mathrm{~s}$ [trnH-psbA]). Finally, an elongation period of $4 \mathrm{~min}[r b c L$ 1F-724R, $t r n L-F]$ or $7 \mathrm{~min}[r b c L$ 636F-1460R, trnH-psbA] at $72^{\circ} \mathrm{C}$ ended the reaction. The PCR products were electrophoresed on $1 \%$ agarose gels in $1 \times$ Tris-borate-EDTA (TBE) buffer ( $\mathrm{pH}$ 8.0) and stained with ethidium bromide to confirm a single product. Afterwards, the cleaned PCR products were sequenced on a 48-capillary ABI 3730 DNA Analyzer using the same primers as in the PCR reactions. A total of 12 new sequences were generated in this study.

Sequences were assembled and edited in Geneious R8 (Kearse et al. 2012), aligned using MAFFT 7 (Katoh et al. 2009; Katoh \& Standley 2013); afterwards, alignments were checked manually in PhyDE 0.9971 (Müller et al. 2010). The alignments used to produce the phylogenies were submitted to Dryad (http:// datadryad.org).

The alignments of the three chloroplast regions were concatenated for the downstream analyses. PartitionFinder 2.1.1 (Lanfear et al. 2012) was used to determine an appropriate data-partitioning scheme from potential partitions that were defined a priori (in this case, each marker was treated as a separate partition plus each codon for the coding marker $r b c L$ ), as well as the best-fitting model of molecular evolution for each partition, using the Bayesian Information Criterion. PartitionFinder suggested the following data-partitioning scheme $(r b c L$ codon $1, r b c L$ codon 2 + codon3, trnH-psbA, trnL-trnF).

Bayesian Inference (BI) analyses were conducted in MrBayes 3.2.6 (Ronquist et al. 2012). For the BI analysis, the F81 model of sequence evolution was determined to be the best-fitting model available in MrBayes for the $r b c L$ codonlpartition, the $\mathrm{HKY}+\mathrm{G}$ model for the $r b c L$ codon $2+\operatorname{codon} 3$ and the $t r n H$ - $p s b A$ partitions, and the HKY model for the trnL-trnF partition in the concatenated data set. Rate heterogeneity, base frequencies, and substitution rates across partitions were unlinked. The analysis was allowed to run for 100 million generations across four independent runs with four chains each, sampling every 10000 generations. Convergence, associated likelihood values, effective sample size values and burn-in values of the different runs were verified with Tracer 1.5 (Rambaut 2010). The first $25 \%$ of the trees from all runs were excluded as burn-in before making a majority-rule consensus of the 7500 posterior distribution trees using the "sumt" function. All phylogenetic analyses were run using the CIPRES portal (http:// www.phylo.org/; Miller et al. 2010). Trees were drawn using FigTree 1.4.3 (Rambaut 2016) and adapted in Adobe Photoshop CS5.

\section{Results}

\section{Molecular Study}

The relationships between the taxa studied are shown in the majority consensus multiple-locus BI tree with the associated posterior probability (PP) values are shown in Fig. 1. As the data for the outgroup taxa are largely based on previous studies (Couvreur et al. 2008a; Parmentier et al. 2013), the relationships in Monodoreae recovered here largely match those already published (Couvreur et al. 2008a; Chatrou et al. 2012; Guo et al. 2017)). Within Monodoreae, a well-supported clade of Orphypetalum and Sanrafaelia $(\mathrm{PP}=1)$ is sister to the rest of the tribe which consists of two main clades. One of these main clades includes two subclades, one $(\mathrm{PP}=0.82)$ representing Asteranthe as sister to Hexalobus + Uvariastrum $(\mathrm{PP}=0.9)$; and the other ( $\mathrm{PP}=0.99)$ including Isolona and Monodora. The other main clade $(\mathrm{PP}=1)$ also includes two subclades, one $(\mathrm{PP}=1)$ representing Uvariodendron as sister to Monocyclanthus and Uvariopsis; and the other consisting of the genus Mischogyne. Mischogyne is well-supported as a monophyletic genus $(\mathrm{PP}=1)$. Within the genus, two well-supported clades are recognisable. The first clade $(\mathrm{PP}=1)$ includes the taxon Mischogyne elliotiana var. gabonensis (further accepted as Mischogyne gabonensis) as sister to two other varieties of Mischogyne elliotiana $(\mathrm{PP}=1)$. The second clade includes Mischogyne michelioides and two species new to science (described below).

\section{Morphological Study}

Study of herbarium specimens supports the recognition of five species and one variety described below. We were unable to discover any discontinuous characters discriminating Mischogyne elliotiana var. glabra from specimens of $M$ elliotiana var. elliotiana. 
Table 1. List of the samples used in the molecular analysis with species names, voucher information, distribution and GenBank accession numbers for the DNA sequences of the three chloroplast regions (*indicates new accessions); a dash (-) indicates missing data.

\begin{tabular}{|c|c|c|c|c|c|}
\hline Species & Voucher & Distribution & $r b c L$ & $\operatorname{trnH}-p s b A$ & $\operatorname{trn} L-F$ \\
\hline $\begin{array}{l}\text { Asteranthe asterias (S.Moore) Engl. } \\
\text { \& Diels }\end{array}$ & $\begin{array}{l}\text { Robertson } 7548 \\
\text { WAG.1379330 }\end{array}$ & Not known & EU169757 & EU169734 & EU169779 \\
\hline Hexalobus crispiflorus A.Rich. & $\begin{array}{l}\text { Sosef } 2287 \\
\quad \text { WAG.1883094 }\end{array}$ & Kenya & EU169760 & EU169737 & EU169782 \\
\hline $\begin{array}{l}\text { Isolona cooperi Hutch. \& Dalziel ex } \\
\text { G.P.Cooper \& Record }\end{array}$ & $\begin{array}{l}\text { Botanische Tuinen } \\
\text { Utrecht } 473 \mathrm{U}\end{array}$ & Not known & AY841626 & EU216657 & AY841704 \\
\hline Monocyclanthus vignei Keay & $\begin{array}{l}\text { Jongkind } 6992 \\
\text { WAG.1434985 }\end{array}$ & Liberia & EU169765 & EU169742 & EU169787 \\
\hline Monodora myristica (Gaertn.) Dunal & Richardson 191 WAG & Not known & AY743447 & EU216670 & AY743466 \\
\hline Ophrypetalum odoratum Diels & $\begin{array}{l}\text { S. A. Robertson } 7547 \\
\text { WAG8004344 }\end{array}$ & Kenya & EU169767 & EU169745 & EU169789 \\
\hline Sanrafaelia ruffonammari Verdc. & Kayombo 3027 MO & Tanzania & EU169768 & EU169746 & EU169790 \\
\hline Uvariastrum insculptum Sprague \& Hutch. & Jongkind $4707 \mathrm{WAG}$ & Ivory Coast & EU169769 & EU169747 & EU169791 \\
\hline Uvariastrum pierreanum Engl. \& Diels & Wieringa 2620 WAG & Gabon & EU169770 & EU169748 & EU169792 \\
\hline Uvariastrum pynaertii De Wild. & PM5033 BRLU & Cameroon & KC628249 & KC667802 & \\
\hline Uvariodendron kirkii Verdc. & Robertson $7550 \mathrm{WAG}$ & Kenya & EU169771 & EU169749 & EU169793 \\
\hline Uvariodendron molundense ( Diels) R.E.Fr. & Sosef 2219 WAG & Gabon & EU169772 & EU169750 & EU169794 \\
\hline $\begin{array}{l}\text { Uvariopsis bakeriana (Hutch. \& Dalziel) } \\
\text { Robyns \& Ghesq. }\end{array}$ & PM5373 BRLU & Cameroon & KC628178 & KC667743 & \\
\hline Uvariopsis korupensis Gereau \& Kenfack & Richardson 212 WAG & Cameroon & EU169774 & EU169752 & EU169796 \\
\hline Uvariopsis tripetala (Baker f.) G.E.Schatz & Jongkind 4356 WAG & Ivory Coast & EU169758 & EU169735 & EU169780 \\
\hline Uvariopsis vanderystii Robyns \& Ghesq. & Sosef $2241 \mathrm{WAG}$ & Gabon & EU169773 & EU169751 & EU169795 \\
\hline Mischogyne congensis Gosline & Evrard $6205 \mathrm{~K}$ & DRC & MH286457* & MH286448* & MH286453* \\
\hline $\begin{array}{l}\text { Mischogyne elliotiana var. elliotiana } \\
\text { (Engl. \& Diels) Le Thomas }\end{array}$ & Came $731 \mathrm{~K}$ & Guinea & MH286458* & MH286449* & MH286454* \\
\hline Mischogyne elliotiana var. sericea Keay & Deighton $3015 \mathrm{~K}$ & Sierra Leone & - & MH286450* & - \\
\hline Mischogyne gabonensis (Le Thomas) Gosline & Luke $11941 \mathrm{~K}$ & $\begin{array}{l}\text { Equatorial } \\
\text { Guinea (Bioko) }\end{array}$ & MH286459* & MH286451* & MH286455* \\
\hline Mischogyne iddii Gosline \& A.R.Marshall & Marshall $1531 \mathrm{~K}$ & Tanzania & - & MH286452* & MH286456* \\
\hline Mischogyne michelioides Exell & Bamps 4459 WAG & Angola & EU169764 & EU169741 & EU169786 \\
\hline
\end{tabular}

\section{Discussion}

\section{Morphology}

Mischogyne are shrubs or small trees $3-7 \mathrm{~m}$ tall or medium-sized trees to $25 \mathrm{~m} \mathrm{(M.} \mathrm{gabonensis,} M$. orientalis). Trunks are cylindrical or branching from the base (M. michelioides). Phyllotaxis is distichous. As is typical for Annonaceae, the very young leaf buds, twigs and leaves are covered with a soft brown appressed indumentum which is quickly lost. Leaves are simple, entire, and exstipulate. Venation is brochidodromous. The tertiary venation is strongly and prominently reticulate and a good character for recognising the genus. Specimens of $M$. congensis were originally identified as M. elliotiana var. glabra; despite being in different clades, the morphological differences in the taxa (see recognition below) are in the leaf venation, acumen, and leaf texture (and of course geographical range). Species can be recognised from the leaves: M. congensis and M. gabonensis have at least some leaves with a linear acumen, with $M$. congensis having much less ascendant nerves. M. elliotiana and M. iddii have triangular acumens or are attenuate, with $M$. iddii having much larger leaves. M. michelioides is deciduous with broad, usually attenuate leaves and grows in a semi-arid environment.
Inflorescences are extra-axillary and one-flowered with the exception of Mischogyne elliotianum which frequently has terminal flowers, and $M$. gabonensis where the type collection has some inflorescences of two flowers. The fundamental inflorescence type for Annonaceae is determinate with a terminal flower. "Apart from (few) exceptions, inflorescences (sometimes reduced to a single flower) appear as lateral structures to the observer, rather than terminal. In the majority of genera this is due to overtopping by a lateral shoot originating from the axil of a leaf immediately below the floral region..." (Maas et al. 2007; Weberling \& Hoppe 1996). This analysis is confirmed for Mischogyne by the often terminal flowers in M. michelioides and examination of young shoots in specimens of M. elliotianum where a young bud can be seen as terminal with a lateral shoot starting to overtop it. Bracts are generally reduced to a tuft or ring of hairs at the base of the pedicel. Small (c. $2 \mathrm{~mm}$ diam.) caducous bracts are sometimes visible on M. michelioides.

Flowers in Mischogyne species are bisexual, trimerous with one whorl of three free sepals (except M. gabonensis) and two subequal alternate whorls of three free petals each. The sepals are generally reduplicate-valvate (van Heusden 1992) in bud, mean- 


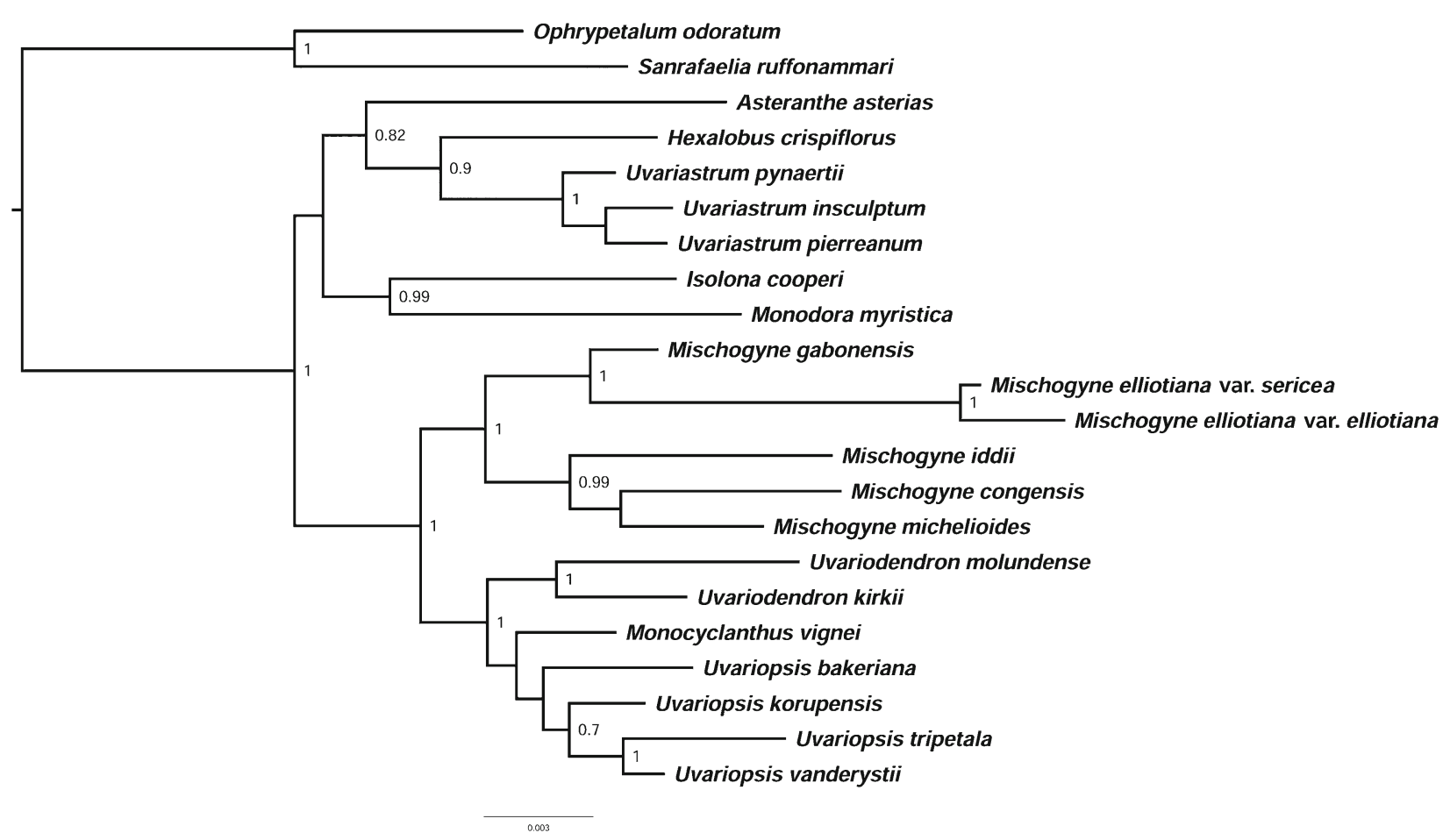

Fig. 1. 50\% majority-rule consensus tree based on BI analysis of the three-locus plastid dataset of the Monodoreae tribe. Posterior probabilities indicated at the respective nodes when equal to or higher than 0.7 .

ing the margins are curved outwards. Reduplicatevalvate sepals are noted as common in genera with middle-sized to large flower buds (van Heusden 1992). Within the tribe Monodoreae this character is also found in the genus Uvariastrum Engl. and in Asteranthe Engl. \& Diels (Couvreur 2014). Mischogyne gabonensis has a membranous connate apiculate calyx which ruptures into two or more fragments as the petals expand and soon falls (Fig. 2D). Van Heusden (1992) records a rupturing calyx in Fusaea, Letestudoxa, some Uvaria, and one Duguetia and Guatteria. The petals are in two whorls with inner and outer petals subequal, white, and covered with a dense indumentum that is finer on the inside. They are reflexed at anthesis, except in $M$. michelioides, curving backwards towards the pedicel and forming a cup-shape at the base enclosing the anthers (Figs 4A, 5A and 7A). David Johnson (review of this paper) points out that reflexed petals are unusual in the Annonaceae and the strong resemblance of the flowers to Hornschuchia Nees. Greenwayodendron Verdc. also has slightly reflexed oblong petals.

The receptacle is more or less extended to form a torus (sometimes referred to as an androgynophore) with stamens spirally arranged on the lower portion and the ovaries in a cluster at the apex. Since the stamens are borne from the base of the receptacle, this structure does not conform to the traditional definition of "androgynophore" which implies a stalk below the stamens (Beentje 2015). It is densely white pubescent. Mischogyne michelioides has a flower with an elongate flexuous torus up to $3 \mathrm{~cm}$ long. The genus Toussaintia Boutique also has an extended cylindrical receptacle (Deroin \& Luke 2005), but is in a different tribe (Uvarieae). Deroin (2000) demonstrates that the gynoecium of Toussaintia is anatomically typical of Annonaceae. To our knowledge, within the Annonaceae only Toussaintia, Mischogyne, and Balonga buchholzii Le Thomas (now Uvaria buchholzii Engl. \& Diels; Zhou et al. 2010) have been described as having an androgynophore. However, many genera have an extended receptacle (torus) (van Heusden 1992), often ovoid with a constricted base; these include Monocyclanthus, Uvariastrum, Uvariopsis and Uvariodendron within the Monodoreae. The receptacle of Mischogyne thus appears to be exceptional only in the degree of elongation of the torus which is made more apparent by the falling of the anthers following anthesis.

The androecium consists of numerous latrorse linear stamens with a connective that lacks the broadened apical prolongation expanded over the anthers typical in the Annonaceae (van Heusden 1992). The connective extension is either absent (Mishogyne michelioides) or slender and rounded, but never expanded over the anthers and glabrous (M. michelioides) or with a tuft of hairs. In most other species of the tribe the connective extensions are compacted together into a pavement-like surface. The stamens are appressed against the torus 


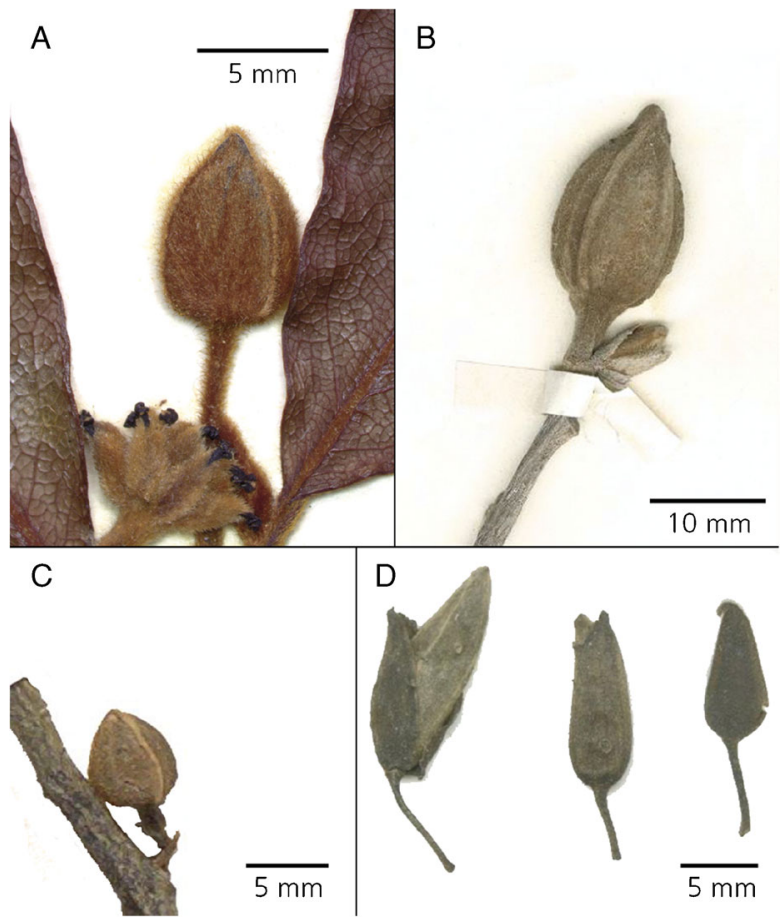

Fig. 2. Flower buds of Mischogyne species. A M. elliotiana var. elliotiana with old flower showing carpels below (Dalziel 761 [K000874259]); B M. michelioides showing large terminal bud (Gossweiler 9379 [K000196792]); C M. congensis (Evrard 5376 [BR0000015312655]); D M. gabonensis buds showing capsule and rupturing at anthesis (Le Testu 1768 [WAG0247284]).

at least at their base, in contrast to Toussaintia and most other Annonaceae. They do not extend past the reflexure of the petals except in M. michelioides. The stamens of $M$. michelioides are among the longest (up to $10 \mathrm{~mm}$ long) of any Annonaceae (van Heusden 1992).

The gynoecium consists of $3-12$ (to 40 in Mischogyne michelioides) separate carpels. The carpels are cylindrical to ovoid covered with a white indumentum as the torus. They are divergent from each other except in $M$. michellioides and extend beyond the petal reflexure. The stigmas are bilobed and sessile except in $M$. elliotiana where a distinct constriction forms a short style.

Fruits consist of a $1-3$ monocarps (field obs.); in herbarium specimens only a single monocarp has been observed. These are ellipsoid or ellipsoid-ovoid, sometimes constricted at one end, and yellow to green with cream or white spots; 3 - 12 seeds per monocarp (Setten et al. 1992).

As with many African groups, nothing is recorded regarding pollination, dispersal, or phytochemistry.

\section{Taxonomy}

As previously circumscribed, the genus Mischogyne consisted of one variable species in West and Central
Africa and another quite different species in Angola. Resulting from our morphological and molecular phylogenetic study, we add a new East African species ( $M$. iddii, described below), a species in the coastal rainforest of Cameroon and Gabon (M. gabonensis, previously accepted as M. elliotiana var. gabonensis), and a species from the Congo river basin (M. congensis, described below). Specimens of the latter had previously been identified as M. elliotiana var. glabra.

We recognise two varieties of Mischogyne elliotiana (Engl. \& Diels) Le Thomas. Mischogyne elliotiana var. glabra Keay was previously recognised on the basis of a lack of indumentum on the branches, but we find the degree of hairiness within the species to vary continuously and reject the variety. On the other hand, the specimens of $M$. elliotiana var. sericea Keay are so distinct in indumentum and leaf size, shape and venation that we maintain the taxon.

\section{Distribution}

The species occur in evergreen or semideciduous equatorial or gallery forest with $1000-4000 \mathrm{~mm}$ precipitation per annum (ppa), apart from the Angolan Mischogyne michelioides Exell which occurs in rocky terrain beneath the coastal escarpment with 650 - $1000 \mathrm{~mm}$ ppa (Map 1).

Apart from Mischogyne michelioides in Angola, the species distribution of the genus now falls into a familiar pattern for tropical African genera: one rather variable species west of the Cross River ("Upper Guinea", White 1979); several (or one in our case) species in Lower Guinea; an isolated midCongo riverine species; and one or more species in East Africa, often in the Eastern Arc mountains. Examples of this distribution pattern abound: Octoknema (Gosline \& Malécot 2011), Isolona (Couvreur et al. 2008b), Polyceratocarpus (Marshall et al. 2016), Octolobus (Cheek \& Frimodt-Møller 1998), and Ancistrocladus (Cheek 2000) are a few examples.

Mischogyne is unusual in also having a species, M. michelioides, in semi-arid coastal Angola. Most Annonaceae species in Angola occur in Cabinda or Lunda provinces in moist Congolian forest. While the other species of Mischogyne are fairly similar to each other, $M$ michelioides has an impressively long receptacle (to $3 \mathrm{~cm}$ ) and very long stamens quite unlike any other Annonaceae (van Heusden 1992). (Sadly we have been unable to locate a photograph of a live flower). It is described as a shrub branched from the base growing in cracks between boulders. The origin and evolution of Mischogyne michelioides is unclear.

Research on tropical African species distribution and speciation has often emphasised Pleistocene refugia as a driving force (e.g. Duminil et al. 2015). 
Couvreur et al. (2008b) demonstrate that the West-East vicariance in other Monodorioid genera occurred in the late Miocene $8-6$ million years BCE (Myr). This separation reflects a world-wide cooling and drying of ecosystems (Herbert et al. 2016). A presumed panAfrican rainforest existed in the mid-Miocene Climatic Optimum (17 - 15 Myr) and explains the common Guinean - Congolean - East African distribution. Estimated Miocene rainforest extent does not show it extending into Angola (Morley 2007). There are small fragments of wet forest in Angola today which Gossweiler (Gossweiler \& Mendonça 1939) refers to as "laurasilva", but these occur to the north of the Mischogyne michelioides distribution. One hypothesis is that wet forest extended along the coast of Angola in the Miocene, and that the population there adapted to drier conditions and possibly a specific pollinator, producing its unusual morphology.

\section{Taxonomic Treatment}

Mischogyne Exell (1932); R. E. Fries (1959); Paiva (1966); Le Thomas (1969). Type species: Mischogyne michelioides Exell

Trees or shrubs. Trunk straight, sometimes fluted, cylindrical, or shrubs branching from the base (M. michelioides). Very young leaf buds, leaves, and twigs with a soft brown indumentum of appressed hairs, quickly glabrous or glabrescent. Twigs striate, light grey to dark grey to brown. Petioles terete, deeply grooved adaxially, glabrous to densely pubescent. Leaves simple, entire, alternate, petiolate and exstipulate, lamina narrowly elliptic to obovate, chartaceous to coriaceous, often slightly bullate, glabrous to pubescent; dark glossy green above, lighter green below, drying olive green concolorous or paler below; midrib impressed on the upper side, raised on the lower side, glabrescent; secondary venation brochidodromous, prominent above and below; tertiary venation markedly reticulate on both surfaces of the lamina with reticulation net cells $0.6-1.8 \mathrm{~mm}$ wide. Inflorescence extra-axillary or terminal (M. michelioides) on young branches, single flowered (occasionally two flowers in M. gabonensis). Bracts generally reduced to a tuft of hairs or early caducous. Flowers bisexual. Sepals 3 , reduplicate-valvate, free, enclosing the receptacle until anthesis (Fig. 2A - C), or united in a thin membranous capsule rupturing at anthesis (M. gabonensis, Fig. 2D). Petals 6, in two alternating whorls of three each, white, free, subequal, elliptic to ovate, pubescent, reflexing at anthesis except M. michelioides where the petals spread from the base. Receptacle extended as a torus, conical, cylindrical, or elongate in a thin flexible column, with stamens attached to the lower portion and carpels attached at the apex. Stamens numerous, spirally arranged, linear, latrorse, basifixed, appressed at least in lower part against the torus; filament minimal or absent; connective and thecae nearly the length of the anther; connective pubescent or glabrous, without expanded terminal extension, connective apex glabrous or terminated by a tuft of hairs. Sepals, petals and stamens dropping at end of anthesis, leaving the receptacle and carpels exposed. Carpels 3-12 (to 40 in M. michelioides), cylindrical to ovoid, densely pubescent; style short or absent, stigma bilobed, ovules numerous, lateral, biseriate, placentation parietal. Fruits monocarps 1 - 3, ellipsoid, oblong to globose, pubescent to glabrous, smooth or with slight longitudinal ribs, constricted or not around the seeds, shortly stipitate, apiculate. Seeds 3 - 12 per monocarp, flattened to transversely ellipsoid, raphe raised to flat, ruminate with 15 - 20 membranous semicircular invaginations.

POLLEN. Pollen in tetrads. Exine reduced, inaperturate, globose, tectum reticulate-perforate. (Doyle \& Le Thomas 2012) Only Mischogyne elliotiana (Walker 1972) and Mischogyne congolana (Le Thomas 1980) have been examined. Doyle \& Le Thomas (2012) give an overview of pollen in the Annonaceae, and show that Mischogyne pollen characters are largely congruent with other genera of Monodoreae. Le Thomas (1980) uses Mischogyne gabonensis as an example of "mixed structure of the infratectile layer", differing slightly from other genera in the clade which have a "columellar structure". Couvreur et al. (2008c) provide a survey of pollen in the other genera of the clade.

ECOLOGY. Evergreen or semideciduous equatorial or gallery forest, with $1000-4000 \mathrm{~mm}$ precipitation per annum (ppa); except Mischogyne michelioides: rivers, sandy areas, or among rocks at altitude $600-1000 \mathrm{~m}$ and $650-1000 \mathrm{~mm}$ rainfall ppa.

POllinAtion. No studies have been done. Saunders (2012) observed that the lack of a pollination chamber is "typical of small-beetle pollination".

DISPERSAL. No scientific observations are known. Dispersal of Mischogyne congensis by snakes cannot be ruled out. "Les indigènes prétendent que les serpents mangeant beaucoup le fruit de cet arbuste." (Gilbert, G.C. 2321bis).

USES. Mischogyne congensis is used against snake bites (Gilbert 2321bis); M. michelioides for treatment of swollen legs (Damann 2557) and against madness (Santos 252). Mischogyne elliotiana var. sericea is used to clean hats and other cloth (Deighton 510).

ETYMOLOGY. $\boldsymbol{\mu} \mid \boldsymbol{\sigma} \chi \mathbf{o s}=\operatorname{stalk}($ Greek $)+$ gyne for the elongate gynoecium of Mischogyne michelioides, the type species. 


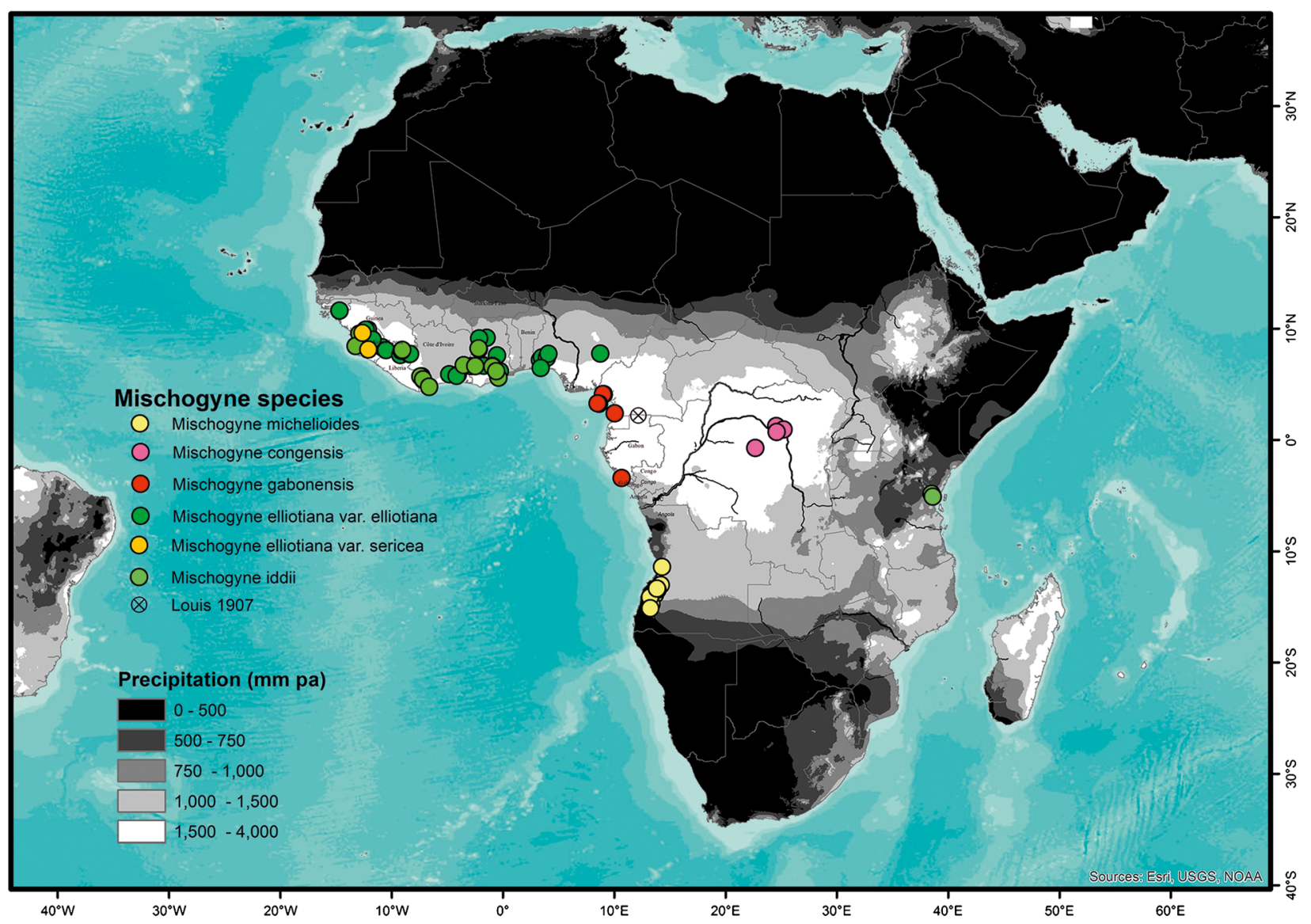

Map 1. Distribution of all species of Mischogyne.

\section{Key to the species of Mischogyne}

1a Torus $>10 \mathrm{~mm}$ long, elongate flexible, leaves deciduous (Angola) $\ldots \ldots \ldots \ldots \ldots \ldots$ 5. M. michelioides

$1 \mathrm{~b}$ Torus $<7 \mathrm{~mm}$ long, cylindrical or connate, leaves evergreen $\ldots \ldots \ldots \ldots \ldots \ldots \ldots \ldots \ldots \ldots 2$

2a Calyx with sepals united, opening by rupturing (Fig. 2D); (Coastal forests Cameroon, Bioko, Gabon) . . . 3. M. gabonensis

2b Calyx of 3 free reduplicate sepals, opening by separation at valvate sepal margins (Fig. 2A, B, C) . . . . 3

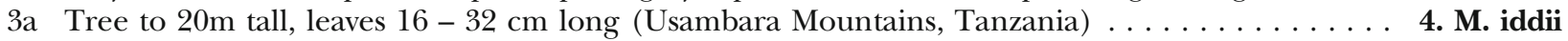

3b Shrub or small tree 3-10 m tall, leaves $8-20 \mathrm{~cm}$ long (West and Central Africa) . . . . . . . . 4

4a Leaves with a wax gloss above and below, secondary nerves ascending at $10^{\circ}-30^{\circ}$ angle to midrib, to $10-20 \%$ of the leaf length before anastomosing; stigma sessile; older petioles glabrous (mid-Congo

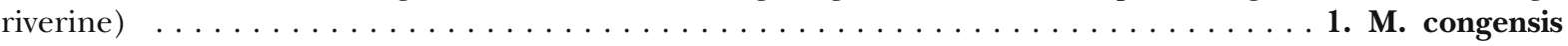

$4 \mathrm{~b}$ Leaves matte below, secondary nerves ascending at $30^{\circ}-45^{\circ}$ angle to midrib, to $25-30 \%$ of the leaf length before anastomosing; stigma on short style; all petioles with indumentum (West Africa) . . . . . . . 5

5a Young leaves glabrous; secondary nerves $6-9$; acumen $8-15 \%$ of the leaf length . . 2a. M. elliotiana var. elliotiana.

5b Underside of young leaves with straight white hairs $0.8-1.2 \mathrm{~mm}$ long, secondary nerves 9 - 12; acumen 20 -

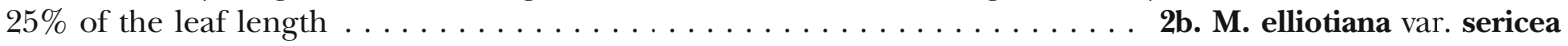

1. Mischogyne congensis Gosline sp. nov. Type: Congo (Kinshasa), Yambuya, 9 Nov. 1956, Evrard 2000 (holotype BR* [BR6102002270390], isotype K! [K000874272]).

http:/ /www.ipni.org/urn:lsid:ipni.org:names:60478273-2
Uvariastrum ellioitianum sensu Boutique, non U. elliotianum Engl. \& Diels (Boutique 1951).

Small tree $3-7 \mathrm{~m}$ tall, to $9 \mathrm{~cm}$ diam.; branches and twigs glabrous; very young twigs with sparse brown appressed hairs $0.1-0.4 \mathrm{~mm}$ long. Twigs light grey to 
brown, roughly striate, glabrescent, youngest shoots and shoot buds covered with light brown hairs 0.1 $0.4 \mathrm{~mm}$ long. Petioles $5-10 \mathrm{~mm}$ long, $1-2 \mathrm{~mm}$ in diam., glabrescent, drying black; very young petioles with sparse hairs $0.1-0.3 \mathrm{~mm}$ long. Leaf lamina narrowly obovate to elliptic, $10-18 \mathrm{~cm}$ long, $3.5-$ $6 \mathrm{~cm}$ wide, length:width ratio $2-3.5$, apex acuminate to caudate, acumen triangular to linear, $1-3 \mathrm{~cm}$ long, $0.2-0.5 \mathrm{~cm}$ wide at mid-length, base cuneate, coriaceous, glabrous on both surfaces, glossy green above and below, drying glossy green to matte light green; midrib glabrous; secondary nerves $8-9$, gradually ascending at $10^{\circ}-30^{\circ}$ angle to midrib to $10-20 \%$ of the leaf length before anastomosing, glabrous. Flowers 1 (-2?) on leafy branches. Flower buds ovoid, $0.6-0.8 \mathrm{~cm}$ long, $0.5-0.6 \mathrm{~cm}$ in diam., with slightly obtuse apex. No bracts seen. Flowering pedicel $0.2-0.9 \mathrm{~cm}$ long, $0.6-1 \mathrm{~mm}$ in diam., densely pubescent, hairs $0.05-0.2 \mathrm{~mm}$ long, appressed, brown. Sepals oblong, $0.8-1 \mathrm{~cm}$ long, $0.5-0.6 \mathrm{~cm}$ wide, length:width ratio 1.5 , base rounded, apex obtuse, pubescent outside and inside, hairs $0.05-0.1 \mathrm{~mm}$ long, light green when fresh, brown in herbarium material. Petals narrowly ovate, $2 \mathrm{~cm}$ long, $0.5 \mathrm{~cm}$ wide, length:width ratio 4 , base rounded, apex rounded, outer surface with dense straight appressed hairs $0.2-0.5 \mathrm{~mm}$ long, inner surface with soft curling hairs $0.1 \mathrm{~mm}$ long, glabrescent, white when fresh. Torus cylindrical, 2 $3.5 \mathrm{~mm}$ long, $1-1.3 \mathrm{~mm}$ diam., densely pubescent with stiff white semi-erect hairs $0.8-1.2 \mathrm{~mm}$ long directed towards apex. Stamens not seen. Carpels $9-$ 16, 3 - $4 \mathrm{~mm}$ long, $1-2 \mathrm{~mm}$ in diam., indumentum as torus; stigma sessile, $0.6-0.8 \mathrm{~mm}$ diam., drying black. Fruits with only one mature monocarp in specimen seen. Monocarp ovoid, $6 \mathrm{~cm}$ long, $3 \mathrm{~cm}$ in diam., with a soft brown indumentum when dried, stipe $1 \mathrm{~cm}$ long, $0.4 \mathrm{~cm}$ in diam. Seeds not seen. Figs 2C, 3.

RECOGNITION. Similar to Mischogyne elliotiana in being a small rainforest shrub or tree with leaves less than $20 \mathrm{~cm}$ long, but differing in: many leaves having a linear acumen arising from the rounded apex of the leaf and 5 times or more as long as wide rather than apex attenuate or acuminate with a triangular acumen $1-3$ times long as wide; secondary nerves ascendant $10-25 \%$ of the leaf length before anastomosing at a distinct angle to a marginal nerve vs ascendant $25-30 \%$ of the leaf length before anastomosing almost parallel with the margin; the leaves drying dark glossy green above and below rather than matte below; the older petioles glabrous rather than having at least some indumentum (Fig. 3).

DISTRIBUTION. Democratic Republic of Congo (Map 1).
SPECIMENS EXAMINED. DEMOCRATIC REPUBLIC OF CONGo. Équateur province: Yalisenga (Mondombe) 380 m, [043'30"S 2240'32"E], fr, 21 April 1959, C. M. Evrard 6205 (BR*, K!); ibid., fl fr, 26 Dec. 1958, C. M. Evrard 5376 (K!). Orientale province: Busukulu Village, Environs do Yangambi Reserve no. 121/ Agri 1953, [043'N 2436'E], 30 Sept. 1947, J. Leonard 1461 (BR*); ibid., 1 Aug. 1947, J. Leonard 1311 (BR*, K!, P*); Bengamisa Yangambi Bengamisa Route vers $45 \mathrm{~km}, 450 \mathrm{~m}$, [0 $\left.^{\circ} 56^{\prime} 28^{\prime \prime N} 25^{\circ} 12^{\prime} 23^{\prime \prime E}\right]$, fl, 21 May 1936, G. Gilbert 2321bis (BR*, K!, $\left.\mathrm{P}^{*}\right)$; Yambuya, $400 \mathrm{~m},\left[1^{\circ} 15^{\prime} 3^{\prime \prime} \mathrm{N}\right.$ 24⒊' $\left.3^{\prime} \mathrm{E}\right], \mathrm{fl}, 1$ Nov. 1956, C. M. Evrard 2000 (BR*, K!, P*).

HABITAT. Riverine forest. Semi-deciduous forest. CONSERVATION STATUS. This taxon is only known from six specimens and four locations on the Congo, Aruwimi, Lindi, and Tshuapa rivers in the Democratic Republic of Congo. The Meise herbarium has 5339 Annonaceae specimens from the DRC, many collected near the biological research station at Yangambi. The existence of only six specimens indicates that the species is rare. The area around Yangambi on the Congo is subject to continuing urbanisation as seen in satellite images. All the locations appear to be impacted by shifting cultivation (Google Earth 2018). Tree cover loss in the 2000 hectares including Yangambi was $18 \%$ from $2000-2017$. Loss along the Lindi river is $45 \%$ in this period (Hansen et al. 2013). Threats from deforestation along the rivers appear to be substantial. The four locations give an EOO of $11618 \mathrm{~km}^{2}$ and an AOO of $16 \mathrm{~km}^{2}$. The indicated IUCN rating is Endangered B1\&2ab(iii).

PHENOLOGY. Flowering in November, December, May. Fruiting April.

VERNACULAR NAME. Inaola a loopa (Turumbu, Leonard 1311).

USES. The leaves and crushed fruits are applied by scarification on the bites of snakes. The local people say that snakes eat a lot of the fruit of this shrub (Gilbert 2321bis).

NOTES. These specimens have previously been determined as Mischogyne elliotiana var. glabra. Their geographic isolation led us to take a closer look. The secondary venation and abrupt long linear acumen indicated a distinct taxon and the molecular phylogenetic hypothesis confirms this taxon as being in a clade with $M$. michelioides and $M$. iddii, the Angolan and Tanzanian taxa, and in a different clade from M. elliotiana.

2. Mischogyne elliotiana (Engl. E ${ }^{\circ}$ Diels) Le Thomas (1969: 285); Hawthorne \& Jongkind (2006). Uvariastrum elliotianum (Engl. \& Diels) Sprague \& Hutch. (Sprague \& Hutchinson 1916: 159), (Keay 1952), (Keay et al. 1952); (Hutchinson et al. 1958); 
(Aubréville 1959); (Keay et al. 1964). Uvaria elliotiana Engl. \& Diels in Engler (1901: 28). Type: Sierra Leone, Talla Hills, Duunia, Mount Gonkwi, 1892, Scott-Elliot 4855 (lectotype, designated by Turner (2013): K! [K000198794], isolectotype B* [B 10 0153004]).

Uvariopsis chevalieri Robyns \& Ghesq. (Robyns \& Ghesquiere 1933). Type: Nigeria, Lokomedji (Lagos) [Olokemeji], July 1905, Chevalier 14069 (holotype $\mathrm{P}^{*}$ [P01960205]).

Shrub or small tree up to $4-7$ (-10) m tall with slender arching habit, trunk cylindrical, up to $12 \mathrm{~cm}$ in diam.; old branches glabrous; young branches glabrous to sparsely pubescent rapidly glabrescent, hairs $0.1-0.3 \mathrm{~mm}$ long, appressed, brown. Bark blackish-green, finely rugose, pustulate; slash yellowish-white, fibrous, strongly scented, "smells like green tomatoes" (Nimba Botanic Team 974). Petioles 3-6 $\mathrm{mm}$ long, 1-2 $\mathrm{mm}$ in diam., with sparse to dense indumentum of hairs $0.2-0.8 \mathrm{~m}$ long. Leaflamina obovate to narrowly elliptic, $8-25 \mathrm{~cm}$ long, $2.5-12 \mathrm{~cm}$ wide, length:width ratio $2-3$, apex acute to attenuate to acuminate, base rounded to acuminate to attenuate, chartaceous to coriaceous, glabrous or with white hairs below on younger leaves (var. sericea), glossy green above when fresh, drying matte, brown to olive, concolorous or lighter below; midrib glabescent above and below to densely pubescent (var. sericea); secondary veins $7-12$, secondary nerves ascending at $30^{\circ}-45^{\circ}$ angle to midrib to $25-30 \%$ of the leaf length before anastomosing. Flowers 1 (-2?). Flower buds ovoid, $0.8-1.5 \mathrm{~cm}$ long, $0.5-$ $1 \mathrm{~cm}$ in diam., apex obtuse. (Fig. 2A). No bracts seen. Flowering pedicel $1-1.5 \mathrm{~cm}$ long, $0.5-1 \mathrm{~mm}$ in diam., pubescent, hairs $0.1-0.3 \mathrm{~mm}$ long, appressed, light brown. Sepals oblong lanceolate, $0.9-1.6 \mathrm{~cm}$ long, 0.5 $0.7 \mathrm{~cm}$ wide, length:width ratio $2-3$, apex acute, base rounded, densely pubescent outside, same as on pedicel, tomentose inside; light green when fresh, light brown in herbarium material. Petals narrowly ovate, $1.5-2 \mathrm{~cm}$ long, $0.5 \mathrm{~cm}$ wide, length:width ratio $3-3.5$, apex acute, base truncate, reflexed at anthesis, outer surface densely pubescent, hairs $0.2-0.5 \mathrm{~mm}$ long, appressed, light brown, inner surface tomentose becoming glabrous, white when fresh, dark brown in herbarium material. Torus columnar, $0.8-3 \mathrm{~mm}$. long, $1-1.5 \mathrm{~mm}$ diam., densely pubescent. Stamens $20-40,1.2-2 \mathrm{~mm}$ long, $0.5-$ $0.8 \mathrm{~mm}$ wide; filament rudimentary, connective visible as a line of hairs between thecae with extension absent or less than $0.1 \mathrm{~mm}$ long, terminating in a tuft of hairs 0.1 $0.2 \mathrm{~mm}$ long. Carpels ellipsoid, 6 - 12, $4.5-5 \mathrm{~mm}$ long, $1.5-2 \mathrm{~mm}$ in diam., densely pubescent, hairs $0.8-$ $1 \mathrm{~mm}$ long, stiff, semi-erect appressed upwards, stigma on a short style $0.4-0.9 \mathrm{~mm}$ long, $0.1 \mathrm{~mm}$ in diam., stigma bilobed, $0.6-1 \mathrm{~mm}$ long and wide, glabrous, yellow drying black. Ovules c. 20 in two series. Fruits with a single mature monocarp in specimens seen. Monocarp $4-10 \mathrm{~cm}$ long, $1.5-$ $6 \mathrm{~cm}$ in diam., ovoid or slightly constricted around seeds, dense indumentum of erect brown to white hairs $0.08-0.1 \mathrm{~mm}$ long, greenish-yellow to yellow; stipe $1.5 \mathrm{~cm}$ long $0.5 \mathrm{~cm}$ diam.

DISTRIBUTION. Guinea-Bissau to Nigeria (Map 1).

HABITAT. Riverine in wet evergreen forests and gallery forests, especially coastal forests (Ivory Coast). In secondary forest in Guinea.

CONSERVATION STATUS. IUCN assessed as LC (Rokni 2016).

PHENOLOGY. Flowering in February - May, November. Fruiting April - November.

ETYMOLOGY. Named for the collector Prof. George Francis Scott Elliot from Kew who collected the type while attached to the Sierra Leone Boundary Commission expedition in 1892.

VERNACULAR NAME. None recorded.

USES. var. sericea: "The old leaves lose their hairs and become hard, and are used for cleaning caps and other cloth articles." (Deighton 510).

NOTES. This species is widespread in West Africa where precipitation exceeds $1000 \mathrm{~mm}$ pa. It grows in a variety of forest habitats. Keay (1952) described three varieties. We have been unable to find any consistent difference between his var. glabrum and the nominate variety. The two remaining varieties are described below.

\section{Key to varieties of Mischogyne elliotiana}

Young leaf blades glabrous, secondary nerves 6 - 9; acumen $5-15 \%$ length of leaf . . . . . . . M. elliotiana var. elliotiana Young leaf blades with sparse indumentum of sericeous white hairs below, secondary nerves 9 - 12, acumen 20 $25 \%$ length of leaf.

\section{2a. Mischogyne elliotiana (Engl. Eं Deils) Le Thomas var. elliotiana \\ Mischogyne elliotiana var. glabrum Keay (1952; 151).}

Shrub or small tree 4- 7 (- 10) $\mathrm{m}$ tall. Petioles 3-6 mm long, $1-2 \mathrm{~mm}$ in diam. Young twigs, petioles and midrib with a strigose $30-60 \%$ cover of hairs $0.3-$
$0.8 \mathrm{~mm}$ long. Leaf lamina obovate to narrowly elliptic, $8-17 \mathrm{~cm}$ long, $4-8 \mathrm{~cm}$ wide, length:width ratio $2-3$, apex attenuate to acuminate, acumen $1-2.5 \mathrm{~cm}$ long, $0.8-1.5 \mathrm{~cm}$ at base, base cuneate; chartaceous to coriaceous, lamina glabrous on both sides; older midribs sometimes sparsely hairy above and below with hairs $0.2-0.3 \mathrm{~mm}$ long; secondary veins $7-9$. 


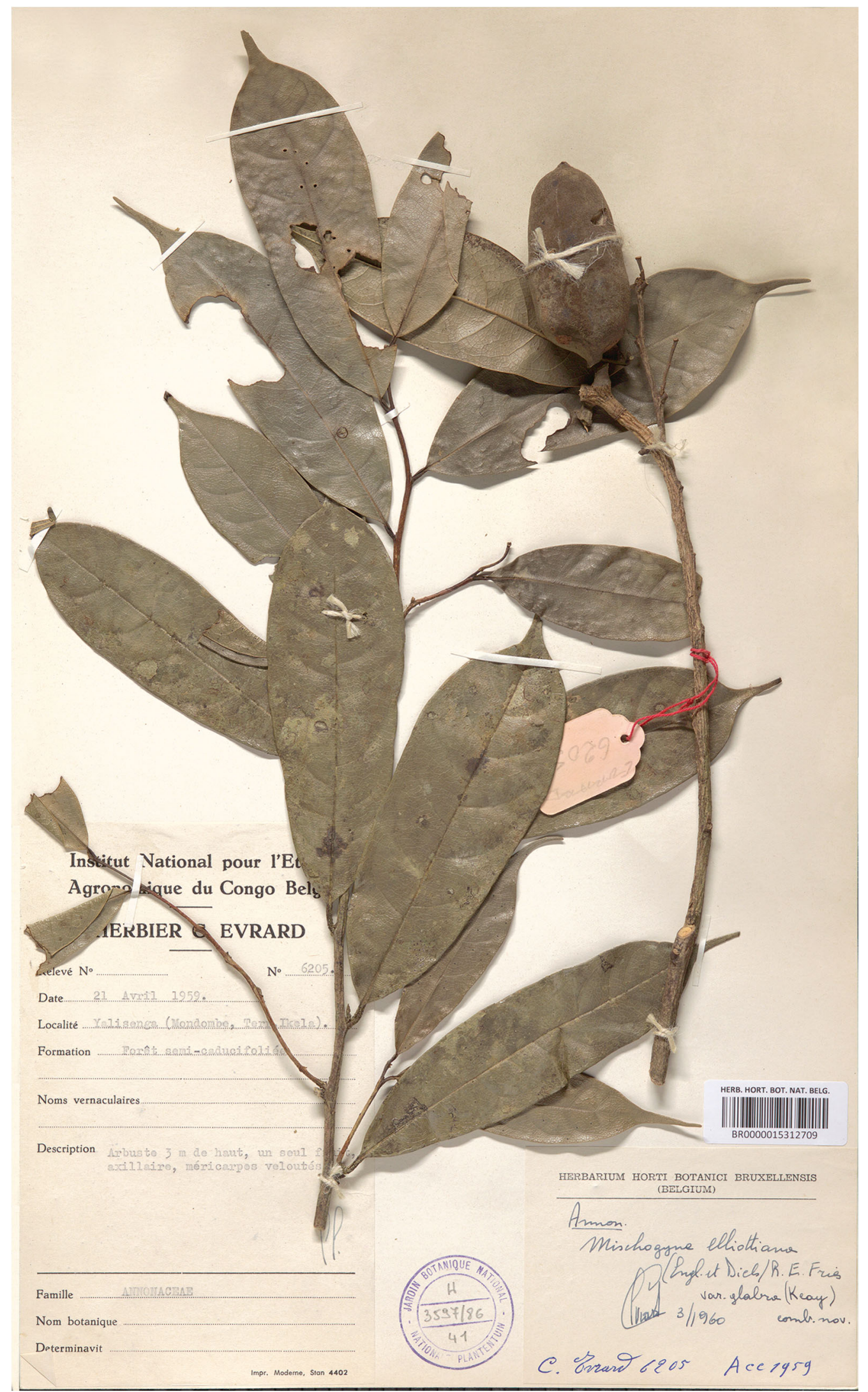

Fig. 3. Mischogyne congensis, fruiting specimen showing linear acumen and secondary veins not ascendant (Evrard 6205 http:// www.botanicalcollections.be/specimen/BR0000015312709). 
Fruit: monocarp 6-10 cm long, $4-6 \mathrm{~cm}$ in diam., yellow or green with white spots, pulp white, edible. Seeds $6-12$ in one or two rows, $2-2.8 \mathrm{~cm}$ long $\times 1.2-1.5 \mathrm{~cm}$ wide by $0.3-0.5 \mathrm{~cm}$ deep, straight on one side, semi-circular on the other, covered with a white membrane (Fig. 4).

SPECIMENS EXAMINED. GUINEA-BISSAU. Bafatá region: Saltinho, margens do rio Corubal, 34 m, [11 $36^{\prime} 52^{\prime \prime N}$ 14²0'58"W], 30 May 1948, J. V. G. Espirito Santo 2481 (K!). GUINEA-CONAKRY. Forécariah Préfecture: Kounoukan Foret Clasee, $2 \mathrm{~km}$ de village Gberebun; district de Kamallaya, dans le chaine de mts Benna, 90 m, [9³2'48"N 1253'5"W], fl, 8 June 2011, N. Camara 713 (K!). Kindia Préfecture: rivière Diani, $466 \mathrm{~m}$, [84'24"N 9²'W], fl, 25 Feb. 1949, J.-G. Adam 3854 (P*); Mamou Préfecture: Sabouya $8 \mathrm{~km} \mathrm{SW}$ from Sabouya, Dalakhoumba $114 \mathrm{~m}, \quad\left[9^{\circ} 54^{\prime} 42^{\prime \prime N}\right.$ $\left.12^{\circ} 7^{\prime} 21^{\prime \prime W}\right], 15$ May 2012, L. Lopez Poveda 145 (K!). Nzérékoré Préfecture: Nimba Mts, plot JRFB06. 605 m, [742'6"N 8²4'29"W], 30 Nov. 2007, Nimba Botanic Team JR974 (MO); plot WHSL05, 513 m, [742'32"N $8^{\circ} 20^{\prime} 37^{\prime W}$ ], 28 Nov. 2007, Nimba Botanic Team WH974 (MO); Sérédou Koïma Tongoro [ $\left.8^{\circ} 16^{\prime} \mathrm{N} 9^{\circ} 6^{\prime} \mathrm{E}\right], 14$ April 1965, F. Camara 2 (BR); Forêt Classée de Mt Yonon next to the Diane R., $480 \mathrm{~m},\left[7^{\circ} 59^{\prime} 15^{\prime \prime} \mathrm{N}\right.$ $\left.9^{\circ} 7^{\prime} 5^{\prime \prime} \mathrm{W}\right]$, fr, 7 May 2011, C. C. H. Jongkind 10664 (L*); Mt Yonon, New Plot 4. $775 \mathrm{~m}, \quad\left[8^{\circ} 0^{\prime} 17^{\prime \prime N}\right.$ 94'38"W], 9 Feb. 2012, E. L. A. N. Simons 827 (L*). Yomou Préfecture: Gpagaye Guinea, Nzérékoré, N of village Gpagaye, $414 \mathrm{~m}$, [7³7'48"N 9¹3'24"W], fl, 3 May 2011, C. C. H. Jongkind 10570 (BR*, L*, P*). SIERRA LEONE. Mount Gonkwi, Duunia, Talla Hills, 640 m, [954'29"N 12²0'1"W], fl, 1 Feb. 1892, G. F. ScottElliot 4855 (B*, K!). Northern province: Southern Sula Mts, SE of Bumbuna, near Kegbema village, $490 \mathrm{~m}$, [90'26"N 11 42'18"W], 19 Nov. 2012, Tonkolili Plants 1324 (K!). Southern province: Bandajuma, $202 \mathrm{~m}$, [8 18'33"N 1051'3"W], 10 May 1914, Aylmer 79 (K!). Western Area (Freetown): Sugar Loaf Mountain Near summit of Sugar loaf at about 2,400 ft, Peninsula, 732 m, [8 $\left.25^{\prime} 19^{\prime \prime} \mathrm{N} 13^{\circ} 13^{\prime} 50^{\prime \prime W}\right], 30$ Jan. 1971, $P . \quad W$. Richards 7100 (K!). LIBERIA. Western Region: Vahun, Kolahun Distr. $249 \mathrm{~m}, \quad\left[8^{\circ} 4^{\prime} \mathrm{N} 10^{\circ} 30^{\prime} \mathrm{W}\right]$, fr, 7 Nov. 1947, J. T. Baldwin Jr 10221 (K!). IVORY COAST. San Pedro, 13 m, [446'N 6 37'45"W], 1 Jan. 1901, Thoiré s.n. ( $\left.\mathrm{P}^{*}\right)$; Moyen-Comoé (Région du): Abengourou, $186 \mathrm{~m}, \quad\left[6^{\circ} 42^{\prime} 41^{\prime \prime N} 3^{\circ} 31^{\prime} 5^{\prime \prime W}\right], 1$ May 1949, Bégué 2988 (P*). GHANA. fl, 1 Jan. 1929, C. Vigne 1630 (P!); Banks of R. Volta, $152 \mathrm{~m}, 1$ April 1929, C. Vigne 1689 (K!); Bonsa Su, May, C. Vigne 1977 (K!). Ashanti Region: Yabi Yabei, $254 \mathrm{~m},\left[6^{\circ} 39^{\prime} 4 " \mathrm{~N}\right.$ 142'32"W], 1 June 1800, C. Vigne 3893 (K!); Near Kwapon, c. $100 \mathrm{~km}$ WSW of Kumasi, $196 \mathrm{~m}$, [6 $37^{\circ} \mathrm{N}$ $\left.2^{\circ} 29^{\prime} \mathrm{W}\right]$, fl, 20 Dec. 1963, R. A. A. Oldeman 777 (K!, $\left.\mathrm{L}^{*}\right)$; Bui Bui, Banda, Brong-Ahafo, by Volta, $100 \mathrm{~m}$,
[8¹3'27"N 2¹1'40"W], 19 May 1961, J. K. Morton 4230 (K!, L*); Eastern Region: Kwahu Prasu $229 \mathrm{~m}$, [6 37'14"N 054'28"W], 1 July 1929, C. Vigne 1628 (K!); Atewa Range F.R., Atewa Range, E.P. (Feb.). 457 $\mathrm{m},\left[6^{\circ} 10^{\prime} \mathrm{N} 0^{\circ} 36^{\prime} \mathrm{W}\right]$, fl, 1 Feb. 1937, C. Vigne 4336 (K!, $\left.\mathrm{P}^{*}\right)$. BENIN. Ouémé Department: Togbota ague, Isaweme, [6 $\left.39^{\prime} \mathrm{N} 2^{\circ} 25^{\prime} 48^{\prime \prime} \mathrm{E}\right], 20$ Nov. 2000, Dan $\mathcal{E}^{\circ}$ Hanon R2:22155 (BR*). NIGERIA. Benue state: Abinsi, Nigeria, [745'N 845'E], 1 June 1912, J. M. Dalziel 761 (BM!, K!). Lagos state: Western Lagos, [6 ${ }^{\circ} 27^{\prime} 11^{\prime \prime} \mathrm{N}$ $3^{\circ} 23^{\prime} 45 " \mathrm{E}$ ], fr, 1 Aug. 1893, J. W. Rowland s.n. (K!); Lagos, fl, 10 Feb. 1906, E. W. Foster 9 (K!, P*). Ogun state: Olokemeji, $79 \mathrm{~m}$, [7²4'33"N 3०30'23"E], fr, 1 July 1905, A. J. B. Chevalier 13998, 14069 (P*); Abeokuta, $25 \mathrm{~m},\left[7^{\circ} 9^{\prime} 44^{\prime \prime N} 3^{\circ} 19^{\prime} 46^{\prime \prime E}\right]$, fr, 1 July 1905, A. J. B. Chevalier 13911 ( $\left.\mathrm{P}^{*}\right)$. Oyo state: Ibadan, $197 \mathrm{~m},\left[7^{\circ} 22^{\prime} 2^{\prime \prime} \mathrm{N}\right.$ $3^{\circ} 56^{\prime} 14 " \mathrm{E}$ ], fr, 6 April 1948, R. W. J. Keay 22828 (K!); Awba R. just $\mathrm{S}$ of Awba Hills and $\mathrm{N}$ of the Oyo -Iwo road, $228 \mathrm{~m}$, [704' $\left.15^{\prime \prime} \mathrm{N} 4^{\circ} 5^{\prime} 22^{\prime \prime} \mathrm{E}\right]$, fr, 22 June 1957, R. W. J. Keay $\mathcal{E}^{\circ}$ H. T. Clifford FHI37071 (K!, $\left.\mathrm{P}^{*}\right)$.

2b. Mischogyne elliotiana (Engl. E var. sericea Keay (1952: 151). Type: Sierra Leone, River bank, Njala, 10 Feb. 1927, Deighton 510 (holotype K! [K000198795], lectotype B!, NSW [NSW459966]).

Shrub or small tree to $5 \mathrm{~m}$ tall. Young twigs, petioles, midrib above and below with a dense indumentum of white hairs $0.8-1.4 \mathrm{~mm}$ long. Petioles 5 - $12 \mathrm{~mm}$ long, $2-4 \mathrm{~mm}$ in diam. Leaf lamina narrowly ovate or ovate to narrowly obovate or obovate, $12-25 \mathrm{~cm}$ long, $5-$ $8 \mathrm{~cm}$ wide, length:width ratio $2.5-4$, apex acuminate or attenuate, acumen $2-4 \mathrm{~cm}$ long, $1.5-2.5 \mathrm{~cm}$ at base, both surfaces with a glabrescent indumentum of appressed white hairs $0.7-1.1 \mathrm{~mm}$ long, strongly coriaceous, drying matte brown, lighter below; midrib secondary veins 9 - 14. Fruit ellipsoid, constricted between seeds when dry, $4 \mathrm{~cm}$ long, $2 \mathrm{~cm}$ diam., apiculate.

DISTRIBUTION. Guinea (Conakry) and Sierra Leone (Map 1).

HABITAT. Lowland forest along rivers.

SPECIMENS EXAMINED. GUINEA (CONAKRY). Kindia Préfecture: Ouélia, Environs de Kindia, Bords de la Kolenté, 60 m, fl, [9³6'23" 12³7'1"], 1 May 1934, H. Jacques-Félix 465 (K!, P*). SIERRA LEONE. Southern province: Njala, R. bank, Njala., $55 \mathrm{~m}$, [8 $6^{\prime} 31^{\prime \prime} 12^{\circ} 5^{\prime}$, 8 July 1935, F. C. Deighton 3015 (K!, SL*); ibid., 10 Feb. 1927, F. C. Deighton 510 (BM!, K!).

PHENOLOGY. Flowering in February, May; Fruiting July. VERNACULAR NAME. None recorded.

USES. "The old leaves lose their hairs and become hard, and are used for cleaning caps and other cloth articles." (Deighton 510). 

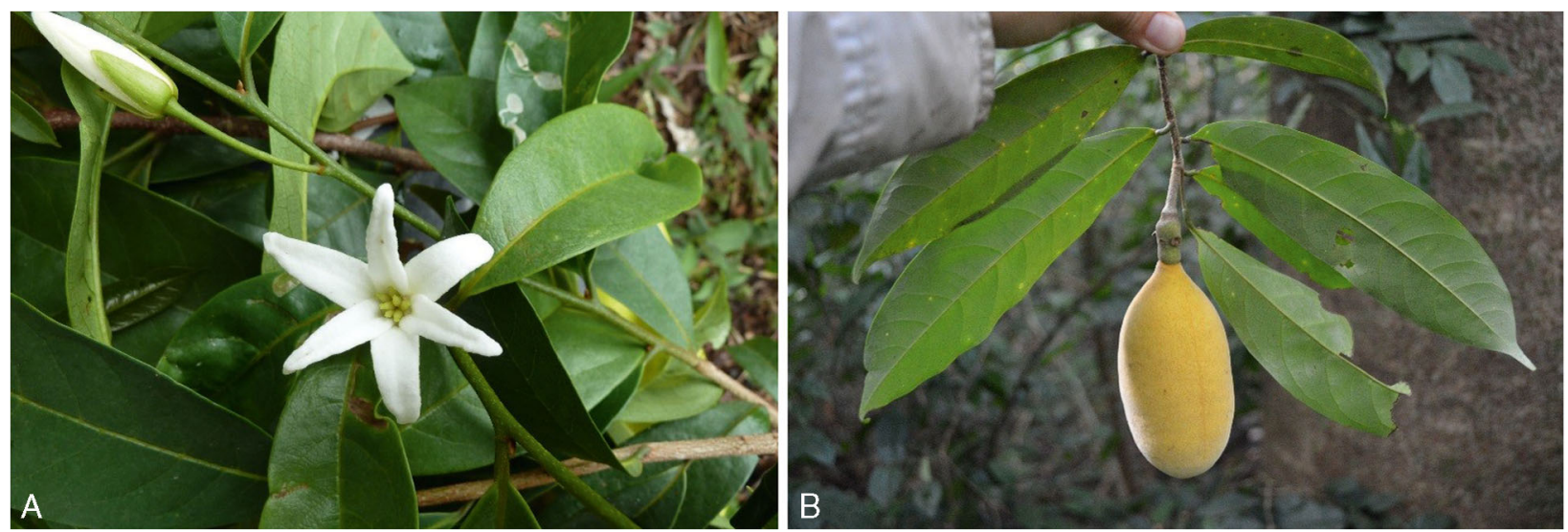

Fig. 4. Mischogyne elliotiana var. elliotiana. A extra-axillary flower; B extra-axillary fruit (Tonkolili Plants 1324). PHOTOS: A CAREL JONGKIND, B XANDER VAN DER BURGT.

NOTES. The larger leathery leaves generally without an acumen together with the glabrescent indumentum of long hairs on the leaves make specimens of this taxon markedly distinct from other Mischogyne elliotiana specimens.

3. Mischogyne gabonensis (Le Thomas) Gosline comb. et stat. nov.

http://www.ipni.org/urn:lsid:ipni.org:names:60478275-2

Mischogyne elliotiana (Engl. \& Diels) Le Thomas var. gabonensis Pellegr. ex Le Thomas, Flore du Gabon 16: 291 (1969). Uvariastrum elliotianum var. gabonensis Pellegr. (Pellegrin 1949), nom. nud. Type: Gabon, Mayumba, region de Nyanga, 26 Aug. 1914, Le Testu 1768 (hololectotype $\mathrm{P}$, sheet here designated [P00315820]; isotypes BM! [BM000547338], BR × 2* [BR0000008801661, BR0000008802330], LISC* [LISC000379], $\mathrm{P} \times$ 2* [P00315817, P00315818], WAG $\times 5^{*}$ [WAG0175098, WAG0175099, WAG0247284, WAG0247285, WAG0247286]).

Tree $3-7$ (-25) $\mathrm{m}$ tall, up to $25 \mathrm{~cm}$ in diam., branches and twigs glabrous. Twigs light grey to brown, striate. Shoot buds with light brown hairs $0.05-0.1 \mathrm{~mm}$ long. Petioles 5 - $10 \mathrm{~mm}$ long, $1.5-2 \mathrm{~mm}$ in diam., sparse indumentum of hairs $0.1 \mathrm{~mm}$ long or glabrous. Leaf lamina obovate, $8-16 \mathrm{~cm}$ long, $4-7 \mathrm{~cm}$ wide, length:width ratio $2-2.5$, apex rounded, abruptly acuminate, acumen linear, $1-3 \mathrm{~cm}$ long, $0.5-1 \mathrm{~cm}$ wide at base, $0.2-0.4$ at mid-length, base cuneate, coriaceous, glabrous on both sides, glossy green above and light green below when fresh, drying matte, olive to brown, lighter below; midrib glabrous above and below; secondary veins $6-9$, ascendant at $30^{\circ}-50^{\circ}$ from midrib to $20-40 \%$ of length of the leaf, anastomosing near margin. Flowers with flower buds $0.7-1.3 \mathrm{~cm}$ long, $0.3-0.5 \mathrm{~cm}$ in diam. Pedicel $0.5-$
$1.2 \mathrm{~cm}$ long, $0.3-0.9 \mathrm{~mm}$ in diam., pubescent, hairs $0.1-0.3 \mathrm{~mm}$ long, appressed, light brown. Sepals united into a thin membranous capsule, ovoid to conical, $0.7-1.3 \mathrm{~cm}$ long, $0.3-0.5 \mathrm{~cm}$ wide, length:width ratio $2-2.5$, base rounded, apex acute or caudate (Fig. 2D). Calyx opens by rupturing, usually, into two parts drying dark brown, tomentose outside and inside, often the tips are lost leaving truncate "sepals", thin, fragile and caducous. Petals narrowly elliptic, $1.4-1.6 \mathrm{~cm}$ long, $0.3-0.5 \mathrm{~cm}$ wide, length:width ratio $3-3.5$, base truncate, apex acute, outer surface densely pubescent, hairs $0.1-0.3 \mathrm{~mm}$ long, appressed, light brown, inner surface tomentose becoming glabrous, white when fresh, inner surface dark brown in herbarium material. Torus truncated conical, $2.2-3 \mathrm{~mm}$. long, 1.5 tapering to $1 \mathrm{~mm}$ diam., upper part densely pubescent. Stamens mounted spirally on lower $60 \%$ of torus but generally fallen in herbarium specimens; carpels at the top, divergent. Stamens 50 - 60, 1 - $3 \mathrm{~mm}$ long, 0.5 - $0.8 \mathrm{~mm}$ wide; yellow when fresh, filament $0.1-0.2 \mathrm{~mm}$ long, connective with an indumentum of hairs $0.1 \mathrm{~mm}$ long between thecae terminating in an extension of $0.1-$ $0.2 \mathrm{~mm}$. Carpels $3-7,3-5.5 \mathrm{~mm}$ long, $1-1.5 \mathrm{~mm}$ in diam., densely pubescent, hairs $0.05-0.2 \mathrm{~mm}$ long, velvety, appressed, white; stigma sessile, bilobed, 1 $1.1 \mathrm{~mm}$ long, $0.6-0.9 \mathrm{~mm}$ wide, glabrous, yellow drying black. Fruits nearly sessile with $1-3$ ovoid monocarps $6-6.5 \times 2.8-3.2 \mathrm{~cm}$, green with white speckles. Seeds 6 in yellow pulp, $2 \times 1.5 \mathrm{~cm}$ with an indumentum of fine white hairs (Fig. 5).

RECOGNITION. Similar to Mischogyne elliotiana in its flowers and fruits. Distinct in being a medium-sized tree to $25 \mathrm{~m}$ tall rather than a small tree or shrub 3-10 m tall; in having $3-7$ carpels rather than 7-12; and in having sepals united in a capsular membranous calyx rather than three free reduplicate-valvate sepals; in the carpel indumentum velvety appressed with hairs $0.05-2 \mathrm{~mm}$ long, rather than with longer bristly semi-erect hairs $0.8-1 \mathrm{~mm}$ long. 
DISTRIBUtION. Cameroon, Bioko (Equatorial Guinea), Gabon (Map 1).

SPECIMENS EXAMINED. CAMEROON. South Region: Nkoolong, Environs de Nko'olong, $30 \mathrm{~km}$ E Campo, B. Satabié 978 (YA not seen). Southwest Region: Njonji, Fako, along path to the lake., $200 \mathrm{~m}$, [4 $4^{\circ} 6^{\prime} 8^{\circ} 59^{\prime}$ ], fr, 26 Sept. 2001, D. Kenfack 1545 (MO*); Bakingili, Mount Cameroon National Park, Bakingili trail, above Bakingili village, $449 \mathrm{~m}, \mathrm{fl}, 2$ April 2016, T. L. P. Couvreur 1033 (photos only). EQUATORIAL GUINEA. Bioko: Moaba - Moka Trail / Pt 141 - Pt 139, 300 m, [316' 8³8'6"], fl, 15 March 2007, W. R. Q. Luke 11941 (K!). GABON. Nyanga Province: Mayumba, région du Nyanga., 24 m, [3²5' 1040'], fl, 26 Aug. 1914, G. M. P. C. Le Testu 1768 (BM*, BR*, L*, LISC*, P*).

HABITAT. Lowland evergreen rain forest.

CONSERVATION STATUS. This taxon is only known from four locations: (1) The Mt Cameroon sites are at the edge of the Mt Cameroon National Park but not within it and subject to community logging. (2) The specimen from the south of Cameroon is not in the Campo-Ma'an National Park, but in an area designated as a production forest. (3) Specimens from Bioko are from within the Reserva Científica de la Caldera de Luba. The forest in the reserve is described as pristine, but a new road is already increasing development pressure in the area (Cronin et al. 2015). (4) The exact location of the Gabonese specimen from Mayumba is unknown and it is not clear that it still exists. A "sustainable" development, including forestry, is planned for the Mayumba area (http:// www.sfmafrica.co.za/projects/gabon). There are threats to plants in three of the four known locations. From the known specimens we compute an AOO of $24 \mathrm{~km}^{2}$ and an EOO of $66192 \mathrm{~km}^{2}$. This justifies an IUCN category of Endangered B2ab(ii).

PHENOLOGY. Flowering in January, November. Fruiting November.

ETYMOLOGY. Meaning 'from Gabon'.

VERNACULAR NAME. None recorded.

USES. None recorded.

NOTES. Annick Le Thomas (1969) described this taxon as a variety in the Flore du Gabon based on Pellegrin's nomum nudum Uvariastrum elliotianum (Engl. \& Diels) Sprague \& Hutch. var. gabonensis. Her diagnosis distinguishes the variety by fewer carpels $(4-5)$ with an attenuate apex and sepals and pedicels puberulent. Her full description appears to be based on Mischogyne elliotiana, and the distinctive capsular calyx is not described.

The specimens from Mt Cameroon occur in one of the wettest environments in Africa with over $4000 \mathrm{~mm}$ ppa. Couvreur records the tree as up to $25 \mathrm{~m}$ tall, $25 \mathrm{~cm}$ diam. (T. L. P. Couvreur 1033), which makes it quite distinct from the smaller and more branched Mischogyne elliotiana. The leaves also have a longer and often linear acumen. This evidence justifies raising this taxon to the species level.
David Kenfack photographed fruits of this species (D. Kenfack 1545) showing hairy seeds (Fig. 6D). Hairy seeds are known from only a few genera (Setten et al. 1992) and this bears further investigation.

4. Mischogyne iddii Gosline $\mathcal{E}$ A.R.Marshall sp. nov. Type: Tanzania, Bomole - PSP13. Amani Nature Reserve, East Usambara Mountains, 15 Oct. 2007, Marshall 1567 (holotype K!) [K000875075].

http://www.ipni.org/urn:lsid:ipni.org:names:60478312-2

Tree, $10-20 \mathrm{~m}$ tall, up to $13-45 \mathrm{~cm}$ in diam., trunk cylindrical; old branches glabrous; young branches and twigs glabrous to sparsely pubescent quickly becoming glabrous, hairs $0.3-0.6 \mathrm{~mm}$ long, appressed, brown. Bark light grey, smooth with horizontally-orientated eyes and fine striations; slash: yellow-brown with a dark brown edge. Petioles $6-8 \mathrm{~mm}$ long, $2-4 \mathrm{~mm}$ in diam., sparsely pubescent with hairs 0.3 - $0.6 \mathrm{~mm}$ long, appressed, white, becoming glabrous, drying black. Leaf lamina elliptic to narrowly elliptic, often slightly falcate, $16-32 \mathrm{~cm}$ long, $6-8 \mathrm{~cm}$ wide, length:width ratio $1.2-4$, apex attenuate to acuminate, acumen triangular $1-2 \mathrm{~cm}$ long, 1 $1.5 \mathrm{~cm}$ at base, leaf base cuneate; coriaceous, slightly bullate when fresh, glabrous on both sides, glossy green above when fresh, drying matte, lighter below; midrib glabrous; secondary veins 10 - 14, glabrous, ascending at $30^{\circ}-45^{\circ}$ from midrib, curving upwards to $10-20 \%$ of length of leaf, anastomosing near margin. Flowers: buds $1.5-2 \mathrm{~cm}$ long, $1 \mathrm{~cm}$ in diam. No bracts seen. Flowering pedicel $0.5-0.8 \mathrm{~cm}$ long, $0.5-1 \mathrm{~mm}$ in diam., pubescent, hairs $0.2-0.3 \mathrm{~mm}$ long, appressed, white to light brown. Sepals ovate to narrowly ovate, $1.5-2 \mathrm{~cm}$ long, $0.5-0.7 \mathrm{~cm}$ wide, length:width ratio $2.5-3$, base rounded, apex acute, densely pubescent outside, same as on pedicel, tomentose inside with soft semi-erect hairs 0.05 $0.1 \mathrm{~mm}$ long; light green when fresh, light brown in herbarium material. Petals narrowly ovate, $1.5-2 \mathrm{~cm}$ long, $0.3-0.8 \mathrm{~cm}$ wide, length:width ratio $2.5-3$, base truncate, apex acute, outer surface densely pubescent, hairs $0.3-0.6 \mathrm{~mm}$ long, appressed light brown, inner surface tomentose with soft semi-erect hairs 0.05 $0.1 \mathrm{~mm}$ long becoming glabrous, white when fresh, dark brown when glabrous in herbarium material. Torus cylindrical, $4-7 \mathrm{~mm}$. long, $2-3 \mathrm{~mm}$ diam., densely pubescent with hairs $0.2-0.4 \mathrm{~mm}$ long. Stamens $4-$ $4.5 \mathrm{~mm}$ long; connective with an indumentum of white hairs $0.1-0.2 \mathrm{~mm}$ long, connective extending $0.1-$ $0.6 \mathrm{~mm}$ beyond anthers ending in a tuft of hairs 0.1 $0.3 \mathrm{~mm}$ long. Carpels $6-9,4-6 \mathrm{~mm}$ long, $1-1.5 \mathrm{~mm}$ in diam., densely pubescent, hairs $0.6-0.8 \mathrm{~mm}$ long, appressed upwards, stigma sessile or on a short style to 

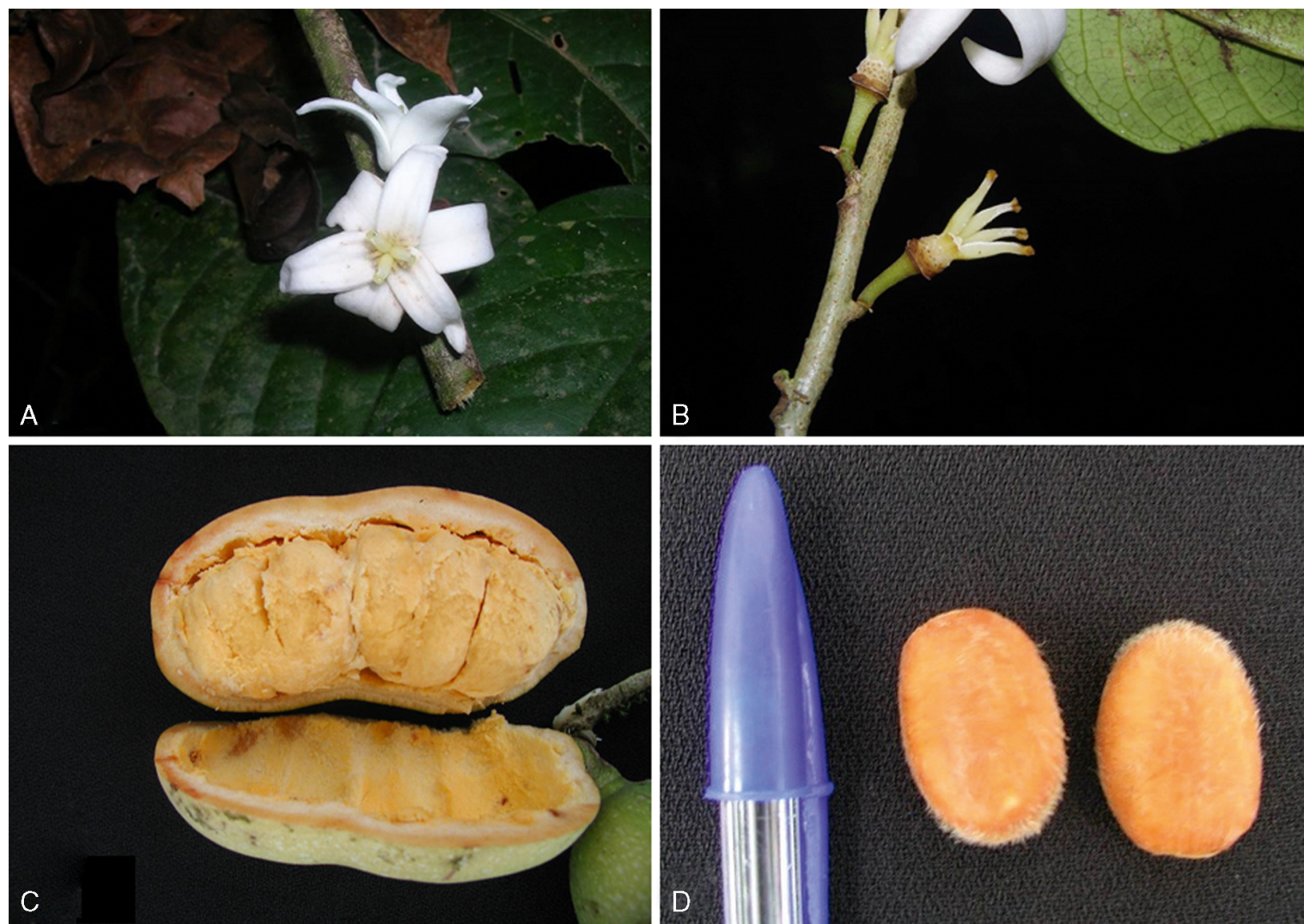

Fig. 5. Mischogyne gabonensis. A flowers (Luke 11941b); B post-anthesis flower (Couvreur 1033); C fruit longitudinally sectioned along long axis (Kenfack 1545); D seeds showing white hairs (Kenfack 1545). PHOTOS: A QUENTIN LUKE, B THOMAS COUVREUR, C, D DAVID KENFACK.

$0.1 \mathrm{~mm}$ long, bilobed, 0.7 - $1.2 \mathrm{~mm}$ long and wide, glabrous, yellow drying black. Fruits unknown (Figs 6, 7).

RECOGNITION. Similar to Mischogyne elliotiana and Mischogyne congensis. Differing in being a mediumsized tree to $20 \mathrm{~m}$ tall rather than a small tree to $8-10$ $\mathrm{m}$ tall; in leaves being larger, up to $32 \mathrm{~cm}$ long rather than to $20 \mathrm{~cm}$.

DISTRIBUTION. Tanzania. Usambara Mountains (Map 1). SPECIMENS EXAMINED. TANZANIA. Tanga: Amani Nature Reserve, East Usambara Mts, UTM 457800E, 9436950S, 15 Oct. 2007, A. R. Marshall 1567 (K! [holotype]), 1271 (K!); Masumbai F.R., W Usambaras, Forest below road from Bambuli to Mazumbai c. $2 \mathrm{~km}$ before Mazumbai, 8 Jan. 1976, Cribb E Grey-Wilson 10082 (DAR, EA, K!).

HABITAT. Mature forest. Growing with Alchornea hirtella Benth., Allanblackia stuhlmannii (Engl.) Engl., Alsodeiopsis schumannii (Engl.) Engl., Anisophyllea obtusifolia Engl. \& Brehmer, Anthocleista grandiflora Gilg, Aoranthe penduliflora (K.Schum.) Somers, Bersama abyssinica Fresen., Blighia unijugata Baker, Celtis africa- na Burm.f., Cephalosphaera usambarensis (Warb.) Warb., Chrysophyllum sp. cf. gorungosanum Engl., Clematis dolichopoda Brenan, Cola sp. cf. greenwayi Brenan, Cynometra brachyrachis Harms, Diospyros loureiriana G.Don, Diospyros occulta F.White, Drypetes usambarica (Pax) Hutch., Englerodendron usambarense Harms, Entandrophragma excelsum (Dawe \& Sprague) Sprague, Ficus lutea Vahl, Ficus natalensis Hochst., Isoberlinia schefflerii (Harms) Greenway, Maesopsis eminii Engl., Magnistipula butayei De Wild., Maranthes goetzeniana (Engl.) Prance, Mesogyne insignis Engl., Myrianthus holstii Engl., Newtonia buchananii (Baker f.) G.C.C.Gilbert \& Boutique, Parinari excelsa Sabine, Placodiscus amaniensis Radlk., Polyalthia suaveolens Engl. \& Diels var. suaveolens, Pouteria adolf-friedericii (Engl.) A.Meeuse, Quassia undulata (Guill. \& Perr.) D.Dietr., Rawsonia lucida Harv. \& Sond., Schefflerodendron usambarense Harms ex Engl., Shirakiopsis elliptica (Hochst.) Esser, Sorindeia madagascariensis DC., Suregada zanzibariensis Baill., Synsepalum cerasiferum (Welw.) T.D.Penn., Trichilia dregeana Sond., Trilepisium madagascariense DC., Xylopia aethiopica (Dunal) A.Rich., 


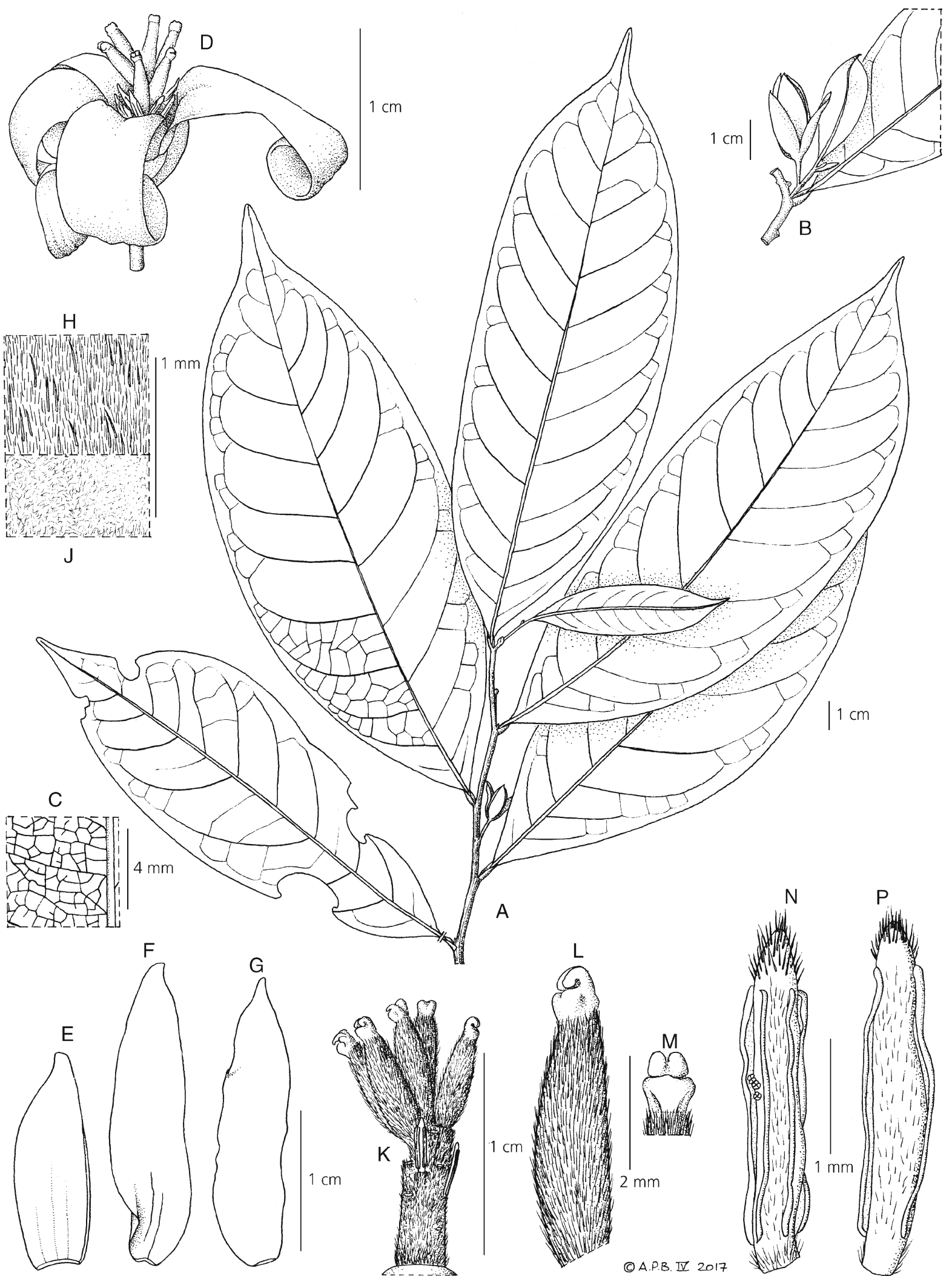

Fig. 6. Mischogyne iddii. A habit, flowering branch; B opening flower bud; C vein network detail; D open flower; $\mathrm{E}$ inner face of sepal; F inner face of outer petal; $\mathrm{G}$ inner face of inner petal; $\mathrm{H}$ detail of hairs on outer face of petal; $J$ detail of hairs on inner face of petal; $\mathrm{K}$ carpels on androgynophore with two stamens in situ; $\mathrm{L}$ carpel; $\mathrm{M}$ stigmatic region of $\mathrm{L}$ viewed from left side; $\mathrm{N}$ outer face of stamen; P inner face of stamen. From Marshall 1567 (K) and photos. DRAWN BY ANDREW BROWN. 
Xymalos monospora (Harv.) Baill., Zanthoxylum gilletii (De Wild.) P.G.Waterman, Zenkerella capparidacea (Taub.) J.Léonard subsp. grotei (Harms) Temu (Marshall et al. 2012).

CONSERVATION STATUS. This tree is known from two locations, one each in the Eastern and Western Usambara Mountains, one in the nationally recognised Amani Nature Reserve and the other in the private Mazumbai reserve managed by the Sokoine University of Agriculture. Both reserves are well managed (Santos 2017). However, a study of ecotourism in Amani shows little benefit to local villages (Shoo \& Songorwa 2013). Cutting of trees for poles continues to be a problem in many Eastern Arc reserves (W. R. Q. Luke, A. R. Marshall, pers. obs.). The reserves are "islands" within a deforested landscape with extensive clearance of forest in neighbouring areas. Invasive tree species, particularly Maesopsis eminii Engl. are also growing extensively in the forest and hence competing with native trees for space (A. R. Marshall pers. obs.). The forest inventory of the Amani Nature Reserve records just six trees of this taxon (A. R. Marshall pers. com.). The Usambaras have been intensively studied for decades. The fact that only seven trees have ever been observed indicates a very small population. We estimate that it is likely that less than fifty individuals remain and that an IUCN category of Critically Endangered under criterion $\mathrm{D}$ is applicable. We take a slightly more conservative approach and, with an AOO of $8 \mathrm{~km}^{2}$ based on a $2 \mathrm{~km}$ grid and two locations, suggest an IUCN category of Endangered B2ab(iii).

PHENOLOGY. Flowering in January, November. VERNACULAR NAMES. Zonozono (Msofu).

USES. None recorded.

ETYMOLOGY. Named in honour of Iddi Rajabu, resident botanist at the Amani Nature Reserve and co-author of the Trees of Amani Nature Reserve field guide.

NOTES. The biological importance of the Eastern Arc Mountains in Kenya and Tanzania is well known (Burgess et al. 2007). Mischogyne iddii joins the long list of Eastern Arc endemic species (ibid.), and new species of Annonaceae continue to be discovered (Couvreur et al. 2006; Couvreur \& Luke 2010; Deroin \& Luke 2005; Marshall et al. 2016; Verdcourt 1986). Couvreur et al. (2006) summarise the high diversity of Annonaceae in Tanzania and this species brings the number of genera in Tanzania to 29 .

5. Mischogyne michelioides Exell (1932: 213); Exell \& Mendonça (1937, 1, 1: 30); Exell \& Mendonça (1951, 1, 2: 356); Fries (1959: Tab. XIII); Paiva (1966: 105). Type: Angola, Quanza-Sul, Seles (Ucu) entre os rios Gunza e Cuvo, 8 Sept. 1930, Gossweiller 9379 (holotype $\mathrm{BM!} \mathrm{[BM000547339];} \mathrm{isotypes} \mathrm{COI*} \mathrm{[COI00071516],}$ $\mathrm{K}$ ! [K000198792], LISC* [K000198792], US* [00098848]).

Deciduous sub-shrub or shrub 1-5 m tall usually branching from the base. Young branches and twigs densely pubescent with hairs $0.5-1.1 \mathrm{~mm}$ long, quickly glabrescent. Bark grey, lightly fissured. Petioles $6-8 \mathrm{~mm}$ long, $1-3 \mathrm{~mm}$ in diam., pubescent with hairs 0.5 $1.1 \mathrm{~mm}$ long, glabrescent. Leaves deciduous, lamina obovate, oblong-obovate, rarely ovate to elliptic, 7 $20 \mathrm{~cm}$ long, $4-8.5 \mathrm{~cm}$ wide, length:width ratio $2-2.5$, apex attenuate to acuminate, rarely obtuse-rounded, base rounded to subcordate, less often cuneate at base, chartaceous, young leaves sparsely pubescent on both surfaces with hairs $0.2-0.8 \mathrm{~mm}$ long, becoming glabrous above and glabrescent below; midrib glabrous above glabrescent below; $8-16$ pairs secondary veins ascendant at $45^{\circ}-60^{\circ}$ to $30-50 \%$ of the leaf length indistinctly
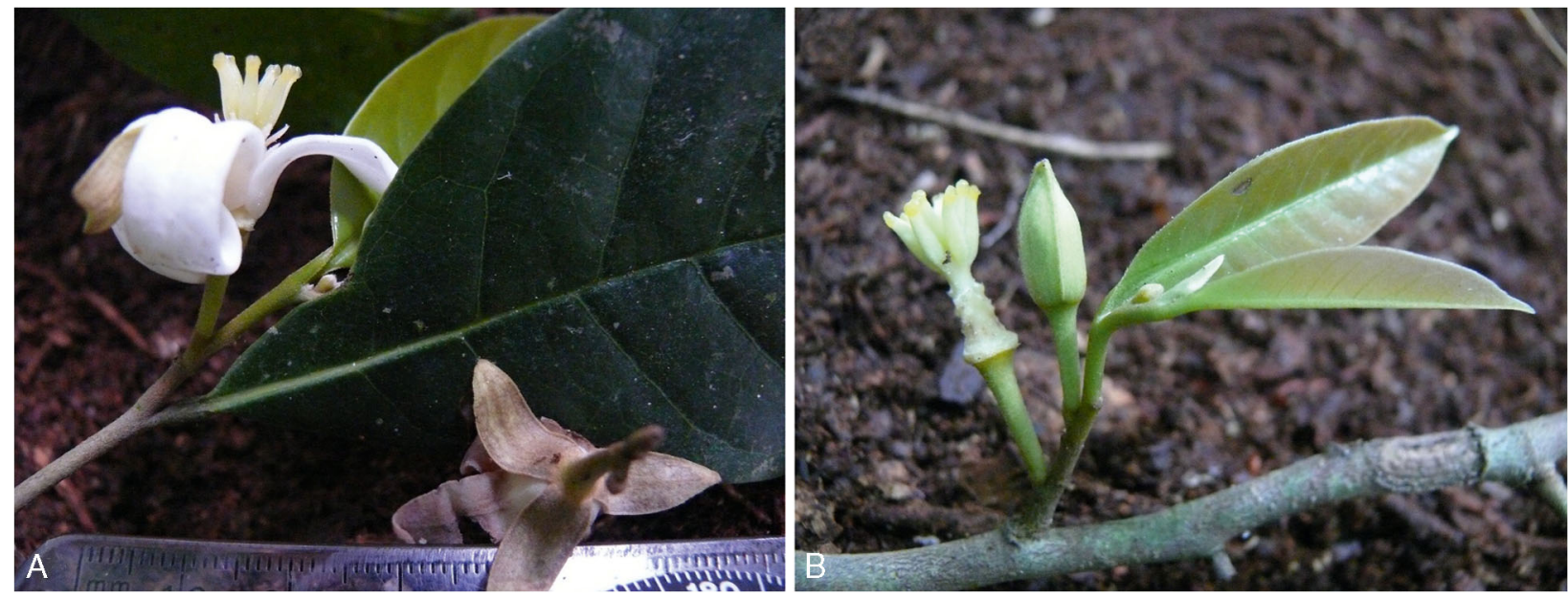

Fig. 7. Mischogyne iddii. A flower; B post-anthesis flower and bud (petals and anthers fallen); bud showing reduplicate calyx similar to Uvariastrum (Marshall 1567). PHOTOS: ANDREW R. MARSHALL. 
anastomosing at margin. Flowers solitary, extra-axillary or terminal, in bud with old leaves, at anthesis with foliar buds and sometimes with young leaves. Flower bud ovoid, $1.5-3 \mathrm{~cm}$ long, $1-2 \mathrm{~cm}$ in diam., apex obtuse to acute. Bracts $1.5-2.5 \mathrm{~mm}$. diam., caducous. Flowering pedicel $0.3-1 \mathrm{~cm}$ long, $0.2-0.3 \mathrm{~cm}$ in diam., densely oppressed pubescent, hairs $0.3-0.6 \mathrm{~mm}$ long, light brown, continuing onto sepals. Sepals broadly ovate-elliptic, 0.9 $1.5 \mathrm{~cm}$ long, $0.5-1 \mathrm{~cm}$ long, length:width ratio $2-2.5$, apex acute, deciduous, green-brown, densely oppressed pubescent on the outside and tomentose-whitish on the inside with hairs $0.08-0.2 \mathrm{~mm}$ long. Petals ovate, narrowly ovate, or oblong-elliptic, $3-4.5 \mathrm{~cm}$ long, $1.1-1.8 \mathrm{~cm}$ wide, length:width ratio $3.5-4$, white, obtuse to rounded at apex, initially thick, becoming thin, densely pubescent on the outside with hairs $0.3-1 \mathrm{~m}$ long, puberulous on the inside with erect hairs $0.08-0.2 \mathrm{~mm}$ long, $7-8 \pm$ parallel ribs from the base, at anthesis fully open and laxly spreading from the base of the torus. Torus cylindrical, $15-30 \mathrm{~mm}$ long, the thicker anther-bearing section at the base $40-60 \%$ of the length $2-2.5 \mathrm{~m}$ in diameter, pubescent with semi-erect hairs $0.2-0.3 \mathrm{~mm}$ long, tapering into a thin $0.8-1.2 \mathrm{~mm}$ diameter pubescent portion with dense white stiff erect hairs $0.3-0.6 \mathrm{~mm}$ long, bearing the spirally-arranged carpels at the top in an ascendant cluster, the pubescence carrying onto the carpels. Stamens numerous, $6-10 \mathrm{~mm}$ long, $0.3-$ $0.6 \mathrm{~mm}$ wide, linear, flexible; connective glabrous, not extending above the thecae; filaments absent. Carpels 8 40, cylindrical, $4-6 \mathrm{~mm}$ long, densely pubescent with stiff white hairs $0.3-0.6 \mathrm{~mm}$ long. Stigmas sessile, bilobed, yellow in dried material. Fruit with pedicel $1 \mathrm{~cm}$ long, pubescent. Monocarps solitary, ovoid-ellipsoid, $5-6 \times$ $2.5-3 \mathrm{~cm}$, apiculate, densely tomentose, dehiscing on plant. Seeds $5-11,2-2.5 \times 1.5 \mathrm{~cm}$, ellipsoid, glabrous (Description partly based on Paiva 1966) (Fig. 8).

DISTRIBUTION. Angola, altitude 700 - 1000 m, western foothills below the scarp of the Central African Plateau. This is the southern end of WWF's "Angolan Scarp savanna and woodlands" biome (WWF n.d.) (Map 1).

HABITAT. Riversides, rocky and sandy areas.

SPECIMENS EXAMINED. ANGOLA. Benguela Province: Cubal - Benguela, km 38, 850 m, fl, [13 $2^{\prime} 14^{\circ} 0^{\prime}$ ], 12 April 1973, P. Bamps 4459 (WAG*) E J J. B. Teixeira 1759 (LISC*); Missão Católica do Cubal, $940 \mathrm{~m}$, [13'1'48" 14¹1'24"], 1 Aug. 1968, J. B. Damann 2557 (LISC*); Seles, Vila Nova de Seles, 850 m, [11 ${ }^{\circ} 24^{\prime} 44^{\prime \prime}$ 14¹8'24"], 12 July 1937, A. W. Exell 3183 (BM!, LISC*); Seles (Ucu), near Cambongo and Queve Rivers, $830 \mathrm{~m}, \quad\left[11^{\circ} 24^{\prime} 1^{\circ} 18^{\prime}\right], 1$ Jan. 1930, J. Gossweiler 9379 (BM!, K!, LISC*); Chongoroi, andados $20 \mathrm{~km}$ de Chongoroi rumo a Benguela, 700 m, [13²1'36" 1350'24"], 16 Nov. 1955, E. J. Mendes 626 (LISC*, WAG*); na serra entre Chongoroi e Cubal (Ganda) andados 10 km do Chongoroi, 18 Nov. 1955,
E. J. Mendes 678 (LISC*, WAG*). Huíla Province: Chao de Chela, Mahila, Vila Arriaga, Bibala, $1000 \mathrm{~m}$, [157'30" 13ํ'12'], 18 Sept. 1941, J. Gossweiler 13221 (LISC*). Namibe Province: Camucuio, a caminho do Mulovei, $700 \mathrm{~m}$, [14 $\left.6^{\prime} 42^{\prime \prime} 13^{\circ} 14^{\prime} 25^{\prime \prime}\right], 29$ Oct. 1962, O. J. A. Menezes 325 (K!, $\left.\mathrm{P}^{*}\right)$; Lungo, Posto Experimental, $688 \mathrm{~m}$, [14 $\left.^{\circ} 19^{\prime} 12^{\prime \prime} 13^{\circ} 12^{\prime}\right]$, 5 March 1956, J. B. Teixeira 688 (LISC*); Caconda, Camucuio, ao longo do Rio Camucuio, $700 \mathrm{~m}$, [14 ${ }^{\circ} 6^{\prime} 13^{\circ} 18^{\prime}$ ], 19 Sept. 1959, J. B. Teixeira E A. M. Andrade 4589, (LISC*); Mossamedes, 30 May 1938, G. de Abreu 54 (BR!).

CONSERVATION STATUS. Specimens were last collected in 1973. Seven locations are known, all along the dry western foothills of the Angolan escarpment. Further research is needed to understand the degree to which these locations share common threats. Woody vegetation in this region is subject to intensive harvesting for charcoal production (Goyder pers. comm.). Existing specimens give an AOO of $48 \mathrm{~km}^{2}$ and an EOO of $16,063 \mathrm{~km}^{2}$. This number of locations and AOO indicate a preliminary category of Vulnerable: VU $\mathrm{B} 1,2 \mathrm{a}, \mathrm{b}(\mathrm{v})$.

PHENOLOGY. Flowering October - December, fruiting July - August. Deciduous and flowering when leafless or with young leaves flushing.

ETYMOLOGY. The specific epithet recognises the resemblance to the Magnoliaceae genus Michelia L., now usually treated as a synonym of Magnolia Plum ex L. "The resemblance to the gynaecium of Michelia is particularly marked.” (Exell 1932).

VERNACULAR NAMES. Munthu, Muntju (Muquilengue), Mundeau (Cubal), Chitundu (Umbundu).

USES. Used as medicine for swollen legs. A tea made from the roots is applied several times a day (Damann 2557). Used by Quimbanda cult against madness (Santos 252).

NOTES. Mischogyne michelioides is unique within the genus in its long $(1-3 \mathrm{~cm})$ and flexible torus, semidry habitat, and deciduous habit. Van Heusden (1992) describes the carpels as "long-stipitate", but the stamens are mounted on the same stalk, so this is apparently an extended receptacle. The stamens (6$10 \mathrm{~mm}$ long) are, besides a few species of Uvaria, the longest in the family (Heusden 1992).

Sympatric Annonaceae in the same habitat are Hexalobus monopetalus (A.Rich.) Engl. \& Diels and Artabotrys antunesii Engl. \& Diels., the former widespread in Africa, the latter endemic to this region of Angola.

ANOMALOUS SPECIMENS. GABON. Woleu Ntem: Village pygmee, $600 \mathrm{~m}$, [12 $^{\circ} 11^{\prime} 2^{\circ} 12^{\prime}$ ], 19 Oct. 1985, Louis 1907 (BR* [BR0000015312594], WAG* [WAG.1434913]) has elliptic leaves with a cuneate base, an attenuate acumen, fruits $8-12 \times 2-4 \mathrm{~cm}$ elongate cylindrical and apiculate. While the reticulate tertiary leaf venation appears correct for 


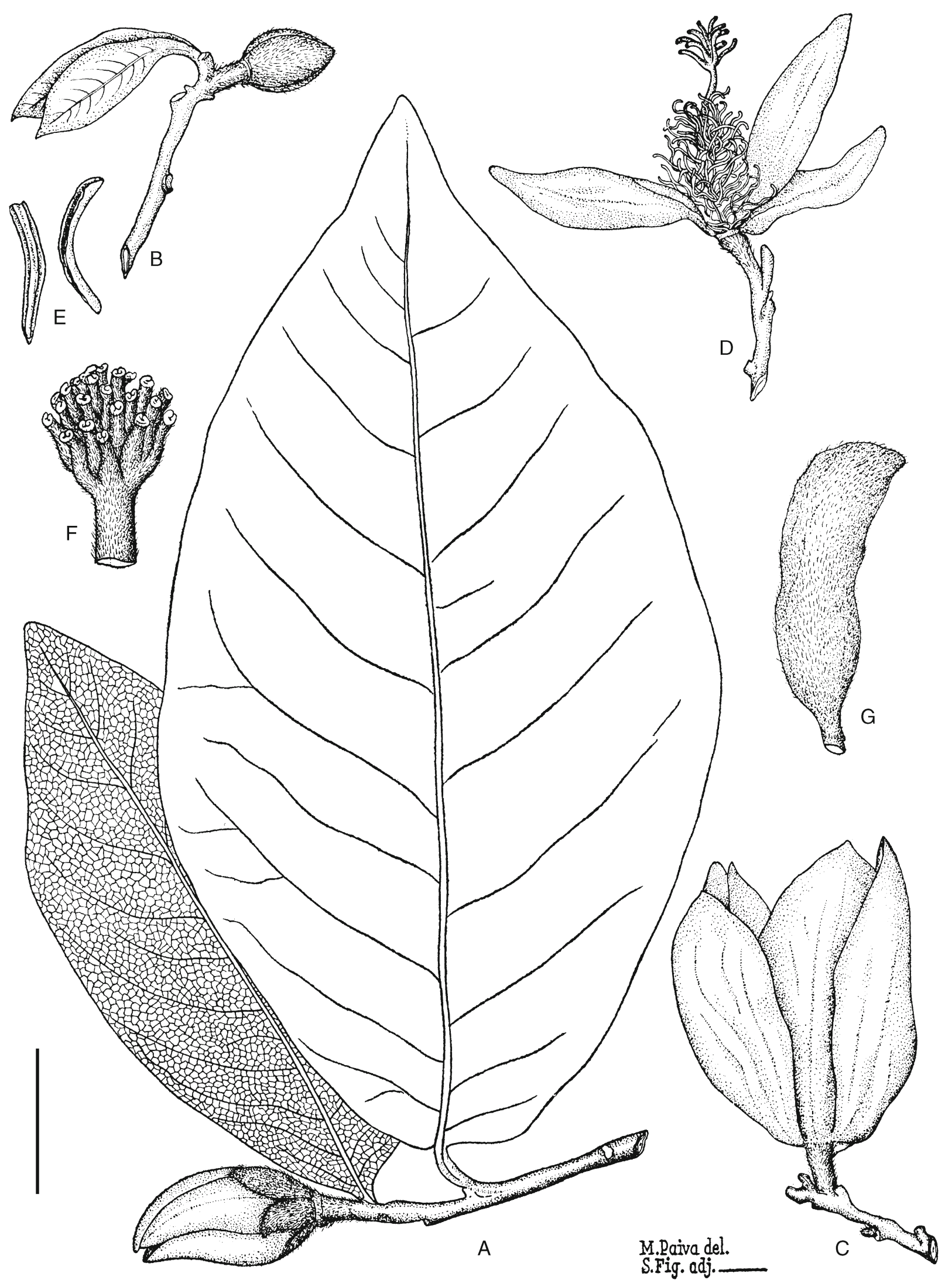

Fig. 8. Mischogyne michelioides. A flowering branch; B branch with bud; C flower with sepals prominent; D flower with 3 petals; $\mathrm{E}$ stamens; F carpels; G monocarp. A, B from Abreu 54; C, E, F from Mendes 678; D from A. Menezes 325; G from Santos 252. Scale bar A - D, G 2 cm; E, F $6 \mathrm{~cm}$. Illustration from Paiva (1966) used with permission. 
Mischogyne the fruit is atypical. More investigation is needed. SÃo TOMÉ AND PRINCIPE. The Meise (BR) database lists a Mann specimen (s.n.) from São Tomé (BR0000015312617). We have not seen this specimen.

\section{Acknowledgements}

GG thanks Xander van der Burgt, Thomas Couvreur, Carel Jongkind, David Kenfack and Quentin Luke for sharing data and use of their photographs. Nina Davies first recognised that Andrew Marshall's collection was a new taxon. Invaluable lab support was provided by Laszlo Csiba at the Jodrell Laboratory of the Royal Botanic Gardens, Kew. Aurélie Grall performed the molecular lab work for Mischogyne iddii. Martin Cheek provided editorial assistance. The research of IL is supported by the B. A. Krukoff Fund for the Study of African Botany. AM was funded through the Valuing the Arc project under the Leverhulme Trust and through Australian Research Council Future Fellowship FT170100279. Thanks to field assistant Iddi Rajabu for assistance with plant identification, and to the Tanzania Wildlife Research Institute, Commission for Science and Technology and Tanzania Forest Service for fieldwork permission. We thank the reviewers, David Johnson and Thomas Couvreur, for their very thorough and useful comments.

Open Access This article is distributed under the terms of the Creative Commons Attribution 4.0 International License (http://creativecommons.org/ licenses/by/4.0/), which permits unrestricted use, distribution, and reproduction in any medium, provided you give appropriate credit to the original author(s) and the source, provide a link to the Creative Commons license, and indicate if changes were made.

\section{References}

Aubréville, A. (1959). La flore forestière de la Côte d'Ivoire. Centre Technique Forestier Tropical, Nogent-sur-Marne.

Bachman, S., Moat, J., Hill, A., de la Torre, J. \& Scott, B. (2011). Supporting Red List threat assessments with GeoCAT: geospatial conservation assessment tool. ZooKeys 150: 117 - 126. https://doi.org/10.3897/ zookeys.150.2109.

Beentje, H. (2015). The Kew Plant Glossary, 2nd Revised ed. Kew Publishing, Richmond.

Botermans, M., Sosef, M. S. M., Chatrou, L. W. \& Couvreur, T. L. P. (2011). Revision of the African genus Hexalobus (Annonaceae). Syst. Bot. 36: 33 48. https://doi.org/10.1600/036364411X553108.
Boutique, R. (1951). Flore du Congo Belge et du RuandaUrundi Vol. II Annonaceae. INEAC, Bruxelles.

Burgess, N. D., Butynski, T. M., Cordeiro, N. J., Doggart, N. H., Fjeldså, J., Howell, K. M., et al. (2007). The biological importance of the Eastern Arc Mountains of Tanzania and Kenya. Biol. Conserv. 134: 209 - 231. https://doi.org/10.1016/ j.biocon.2006.08.015.

Chaowasku, T., Johnson, D. M., van der Ham, R. W. J. M. \& Chatrou, L. W. (2015). Huberantha, a replacement name for Hubera (Annonaceae: Malmeoideae: Miliuseae). Kew Bull. 70: 23. https://doi.org/10.1007/s12225-015-9571-z.

Chatelain, C., Aké Assi, L., Spichiger, R. \& Gautier, L. (2011). Cartes de distribution des plantes de Côte d'Ivoire. (Vol. 64). doi:10.13140/RG.2.1.2491.5925

Chatrou, L. W. (1998). Changing Genera: Systematic Studies in Neotropical and West African Annonaceae. PhD dissertation, Universiteit Utrecht, Utrecht.

Pirie, M. D., Erkens, R. H. J., Couvreur, T. L. P., Neubig, K. M., Abbott, J. R., et al. (2012). A new subfamilial and tribal classification of the pantropical flowering plant family Annonaceae informed by molecular phylogenetics. Bot. J. Linn. Soc. 169: $5-$ 40. https://doi.org/10.1111/j.10958339.2012.01235.x.

Cheek, M. (2000). A synoptic revision of Ancistrocladus (Ancistrocladaceae) in Africa, with a new species from Western Cameroon. Kew Bull. 55: 871 - 882. https://doi.org/10.2307/ 4113632.

\& Frimodt-Møller, C. (1998). The genus Octolobus (Sterculiaceae) new to East Africa. Kew Bull. 53: 682 - 682. https://doi.org/10.2307/4110486.

Couvreur, T. L. P. (2009). Monograph of the syncarpous African genera Isolona and Monodora (Annonaceae). Syst. Bot. Monogr. 87: 1 - 150.

(2014). Revision of the African genus Uvariastrum (Annonaceae). PhytoKeys 33: 1 - 40. https:// doi.org/10.3897/phytokeys.33.5907.

\& Annonaceae Community. (n.d.). World Annonaceae. http://annonaceae.myspecies.info/. Accessed July 2018.

, Botermans, M., van Heuven, B. J. \& van der Ham, R. W. J. M. (2008c). Pollen morphology within the Monodora clade, a diverse group of five African Annonaceae genera. Grana 47: 185 - 210. https://doi.org/10.1080/00173130802256913.

, Chatrou, L. W., Sosef, M. S. \& Richardson, J. E. (2008b). Molecular phylogenetics reveal multiple tertiary vicariance origins of the African rain forest trees. BMC Biol. 6: 54. https://doi.org/10.1186/ 1741-7007-6-54.

Gereau, R., Wieringa, J. \& Richardson, J.-E. (2006). Description of four new species of Monodora 
and Isolona (Annonaceae) from Tanzania and an overview of Tanzanian Annonaceae diversity. Adansonia 28: 243 - 266.

\& Luke, W. R. Q. (2010). A new species of Uvariopsis (Annonaceae), endemic to the Eastern Arc Mountains of Tanzania. Blumea 55: 68 - 72. https://doi.org/10.3767/000651910X499196.

, Niangadouma, R., Sonké, B. \& Sauquet, H. (2015). Sirdavidia, an extraordinary new genus of Annonaceae from Gabon. PhytoKeys 46: 1 - 19. https://doi.org/10.3897/phytokeys.46.8937.

Richardson, J. E., Sosef, M. S. M., Erkens, R. H. J. \& Chatrou, L. W. (2008a). Evolution of syncarpy and other morphological characters in African Annonaceae: A posterior mapping approach. Molec. Phylogenet. Evol. 47: 302 - 318. https://doi.org/ 10.1016/j.ympev.2008.01.018.

, van der Ham, R. W. J. M., Mbele, Y. M., Mbago, F. M. \& Johnson, D. M. (2009). Molecular and morphological characterization of a new monotypic genus of Annonaceae, Mwasumbia from Tanzania. Syst. Bot. 34: 266 - 276. https://doi.org/10.1600/ 036364409788606398.

Cronin, D. T., Bocuma Meñe, D., Perella, C., Fernández, D., Hearn, G. W. \& Gonder, M. K. (2015). The Future of the Biodiversity of the Gran Caldera Scientific Reserve: Translating Science into Policy to Develop an Effective Management Plan for the Gran Caldera Scientific Reserve. Report prepared for the Symposium on the Future of the Biodiversity of the Gran Caldera Scientific Reserve by the Bioko Biodiversity Protection Program. Http:// www.bioko.org/assets/2015_bbpp_gcsr_workshopwhite-paper_v6_english_online.pdf [accessed 7 June 2018].

Deroin, T. (2000). Floral Anatomy of Toussaintia hallei Le Thomas, a case of convergence of Annonaceae with Magnoliaceae. In: Y. Liu, H. Fan, Z. Chen \& Q. W. Zeng (eds), Proceedings of the International Symposium on the family Magnoliaceae 1998, pp. 14 - 25. Science Press, Beijing.

\& Luke, Q. (2005). A new Toussaintia (Annonaceae) from Tanzania. J. E. Afr. Nat. Hist. 94: 165 - 174. https://doi.org/10.2982/00128317(2005)94[165:ANTAFT]2.0.CO;2.

Doyle, J. A. \& Le Thomas, A. (2012). Evolution and phylogenetic significance of pollen in Annonaceae. Bot. J. Linn. Soc. 169: 190 - 221. https://doi.org/ 10.1111/j.1095-8339.2012.01241.x.

Doyle, J. J. \& Doyle, J. L. (1990). Isolation of plant DNA from fresh tissue. Focus 12: 13 - 15.

Duminil, J., Mona, S., Mardulyn, P., Doumenge, C., Walmacq, F., Doucet, J. \& Hardy, O. (2015). Late Pleistocene molecular dating of past population fragmentation and demographic changes in African rain forest tree species supports the forest refuge hypothesis. J. Biogeogr. 42: 1443 1454. https://doi.org/10.1111/jbi.12510.

Engler, H. D. A. (1901). Monographien Afrikanischer Pflanzen-Familien und Gattungen 6: 28. W. Engelmann, Leipzig.

ESRI (2011). ArcGIS Desktop: Release 10.1. Redlands, CA: Environemental Systems Research Institute.

Evrard, C. (1967). Noms et combinaisons nouveaux pour la flore du Secteur forestier central congolais. Bull. Jard. Bot. Natl. Belg. 37: 457 - 460. https:// doi.org/10.2307/3667470.

Exell, A. W. (1932). Mr. John Gossweiler's plants from Angola and Portuguese Congo. Dicotyledones: Polypetalae. J. Bot. 70 (Suppl. 1). \& Mendonça, F. A. (1937). Conspectus Florae Angolensis. Universidade de Coimbra, Instituto Botânico, Coimbra.

\& Mendonça, F. A. (1951). Conspectus Florae Angolensis. Addenda et corrigenda Ministerio de Ultramar, Lisboa.

Fay, M. F., Swensen, S. M. \& Chase, M. W. (1997). Taxonomic affinities of Medusagyne oppositifolia (Medusagynaceae). Kew Bull. 52: 111 - 120.

Bayer, C., Alverson, W. S., de Bruijn, A. Y. \& Chase, M. W. (1998). Plastid $r b c L$ sequence data indicate a close affinity between Digodendron and Bixa. Taxon 47: 43 - 50.

Fero, M., Aedo, C., Cabezas, F. \& Velayos, M. (2014). Taxonomic Revision of Neostenanthera (Annonaceae). Syst. Bot. 39: 17 - 30. https:// doi.org/10.1600/036364414X678071.

Fries, R. E. (1955). Verstreute Beobachtungen hinsichtlich der Familie Annonaceae. Ark. Bot. 3: $35-42$.

(1959). Annonaceae. In: H. Melchior (ed.), Die Natülichen Pflanzenfamilien, 2nd ed., pp. 1 - 171. Dunker \& Humblot, Berlin.

Ghogue, J.-P., Sonké, B. \& Couvreur, T. L. P. (2017). Taxonomic revision of the African genera Brieya and Piptostigma (Annonaceae). Pl. Ecol. Evol. 150: 173 - 216. https://doi.org/10.5091/ plecevo.2017.1137.

Gosline, G. \& Malécot, V. (2011). A monograph of Octoknema (Octoknemaceae - Olacaceae s.1.). Kew Bull. 66: 367 - 404.

Gossweiler, J. \& Mendonça, F. A. (1939). Carta fitogeográfica de Angola: memória descritiva dos principais tipos de vegetação da colónia determinados pelos seus aspectos fisiográficos da carateres ecológicos segundo a nomenclatura de Rübel. Edição do Governo Geral de Angola, Lisbon.

Guo, X., Cheung Tang, C., Thomas, D. C., Couvreur, T. L. P. \& Saunders, R. (2017). A mega-phylogeny 
of the Annonaceae: Taxonomic placement of five enigmatic genera and support for a new tribe, Phoenicantheae. Sci. Rep. 7: 7323. https://doi.org/ 10.1038/s41598-017-07252-2.

Hamilton, M. B. (1999). Four primer pairs for the amplification of chloroplast intergenic regions with intraspecific variation. Molec. Ecol. 8: 521 - 523.

Hansen, M. C., Potapov, P. V., Moore, R., Hancher, M., Turubanova, S. A., Tyukavina, A., et al. (2013). High-Resolution Global Maps of 21st-Century Forest Cover Change. Science 342: 850 - 853. https:// doi.org/10.1126/science.1244693.

Hawthorne, W. \& Jongkind, C. (2006). Woody Plants of Western African Forests: A Guide to the Forest Trees, Shrubs and Lianes from Senegal to Ghana. Royal Botanic Gardens Kew.

Herbert, T. D., Lawrence, K. T., Tzanova, A., Peterson, L. C., Caballero-Gill, R. \& Kelly, C. S. (2016). Late Miocene global cooling and the rise of modern ecosystems. Nature Geosci. 9: 843 - 847. https:// doi.org/10.1038/ngeo2813.

van Heusden, E. C. H. (1992). Flowers of Annonaceae: Morphology, classification, and evolution. Blumea, Suppl. 7: $1-218$.

Hutchinson, J., Dalziel, J. \& Keay, R. (1958). Flora of west tropical Africa ... Vol. 1. Crown Agents for Overseas Governments \& Administrations, London.

IUCN (2012). IUCN Red List Categories and Criteria: Version 3.1. IUCN, Gland and Cambridge.

Katoh, K., Asimenos, G. \& Toh, H. (2009). Multiple Alignment of DNA Sequences with MAFFT. In: D. Posada (ed.), Bioinformatics for DNA Sequence Analysis, Methods in Molecular Biology (Methods and Protocols). (Vol. 537), pp. 39 - 64. Humana Press. doi: 10.1007/978-1-59745-251-9_3

\& Standley, D. M. (2013). MAFFT multiple sequence alignment software version 7: improvements in performance and usability. Molec. Biol. Evol. 30: 772 - 780. https://doi.org/10.1093/ molbev/mst010.

Kearse, M., Moir, R., Wilson, A., Stones-Havas, S., Cheung, M., Sturrock, S., et al. (2012). Geneious Basic: an integrated and extendable desktop software platform for the organization and analysis of sequence data. Bioinformatics 28: 1647 - 1649. https://doi.org/10.1093/bioinformatics/bts199.

Keay, R. W. J. (1952). Revision of the "Flora of West Tropical Africa": I. Kew Bull. 7: 149 - 165. https:// doi.org/10.2307/4109256.

, Hutchinson, J. \& Dalziel, J. (1952). Flora of West Tropical Africa, 2nd ed. Vol. I. Crown Agents for Overseas Governments \& Administrations, London.

Onochie, C. F. A. \& Stanfield, D. P. (1964). Nigerian trees. Federal Dept. of Forest Research, Ibadan.

Lanfear, R., Calcott, B., Ho, S. Y. W. \& Guindon, S. (2012). PartitionFinder: combined selection of partitioning schemes and substitution models for phylogenetic analyses. Molec. Biol. Evol. 29: 1695 1701. https://doi.org/10.1093/molbev/mss020.

Lanjouw, J. (1952). International code of botanical nomenclature adopted by the Seventh International Botanical Congress, Stockholm, July 1950. International Bureau for Plant Taxonomy and Nomenclature of the International Association for Plant Taxonomy, Utrecht. https://catalog.hathitrust.org/Record/ 002000241 . Accessed 1 June 2018.

Le Thomas, A. (1969). Annonacées. Flore du Gabon 16. Museum National d'histoire Naturelle, Paris.

(1980). Ultrastructural characters of the pollen grains of African Annonaceae and their significance for the phylogeny of primitive Angiosperms. Part 1 Pollen et Spores 22: 267 - 342.

Maas, P. J. M., Westra, L. Y. T. \& Vermeer, M. (2007). Revision of the Neotropical genera Bocageopsis, Onychopetalum, and Unonopsis (Annonaceae). Blumea 52: 413 - 554. https://doi.org/10.3767/ 000651907 X608909.

Marshall, A. R., Willcock, S., Platts, P. J., Lovett, J. C., Balmford, A., Burgess, N. D., et al. (2012). Measuring and modelling above-ground carbon and tree allometry along a tropical elevation gradient. Biol. Conserv. 154: 20 - 33. https://doi.org/10.1016/ j.biocon.2012.03.017.

Couvreur, T. L. P., Summers, A. L., Deere, N. J., Luke, W. R. Q., Ndangalasi, H. J., Sparrow, S. \& Johnson, D. M. (2016). A new species in the tree genus Polyceratocarpus (Annonaceae) from the Udzungwa Mountains of Tanzania. PhytoKeys 63: 63 - 76. https://doi.org/10.3897/phytokeys.63.6262.

Miller, M. A., Pfeiffer, W. \& Schwartz, T. (2010). Creating the CIPRES Science Gateway for Inference of Large Phylogenetic Trees. In: 2010 Gateway Computing Environments Workshop (GCE 2010), pp. 1 - 8. New Orleans, LA. 10.1109/GCE.2010.5676129

Morley, R. J. (2007). Cretaceous and Tertiary climate change and the past distribution of megathermal rainforests. In: Tropical Rainforest Responses to Climatic Change, pp. 1 - 31. Springer, Berlin and Heidelberg. doi: 10.1007/978-3-540-48842-2_1

Müller, J., Müller, K., Neinhuis, C. \& Quandt, D. (2010). PhyDE-Phylogenetic Data Editor, version 0.9971. Available at http://www.phyde.de/ (accessed 10 January 2016).

Paiva, J. A. R. (1966). Revisão das Annonaceae de Angola. Mem. Soc. Brot. 19: 5 - 128.

Parmentier, I., Duminil, J., Kuzmina, M., Philippe, M., Thomas, D. W., Kenfack, D., Chuyong, G. B., Cruaud, C. \& Hardy, O. J. (2013). How Effective Are DNA Barcodes in the Identification of African Rainforest Trees? PLoS ONE 8: e54921. https:// doi.org/10.1371/journal.pone.0054921.

Pellegrin, F. (1949). Les Annonacées du Gabon (suite 5). Mém. Soc. Bot. France, Mem. 31. 
Rambaut, A. (2010). Tracer 1.5. A program for analyzing the trace files generated by Bayesian MCMC runs. https://www.softpedia.com/get/Science-CAD/Tracer-AR.shtml

(2016). FigTree version 1.4.3. Available at http:/ / tree.bio.ed.ac.uk/software/figtree/ (accessed 10 January 2017).

Robyns, W. \& Ghesquiere, J. (1933). Essai de révision des genres Uvariopsis Engl. et Diels et Tetrastemma Diels (Annonacées). Ann. Soc. Sci. Bruxelles, Ser. B53: 312 - 322.

Rokni, S. (2016). Mischogyne elliotianum. The IUCN Red List of Threatened Species 2016: e.T85729141A85729179. 10.2305/IUCN.UK.20161.RLTS.T85729141A85729179.en

Ronquist, F., Teslenko, M., van der Mark, P., Ayres, D. L., Darling, A., Höhna, S., et al. (2012). MrBayes 3.2: Efficient Bayesian Phylogenetic Inference and Model Choice Across a Large Model Space. Syst. Biol. 61(3): 539 - 542. https://doi.org/10.1093/sysbio/sys029.

Samarakoon, T., Wang, S. Y. \& Alford, M. H. (2013). Enhancing PCR amplification of DNA from recalcitrant plant specimens using a trehalose-based additive. Applications Pl. Sci. 1: 1200236. https:// doi.org/10.3732/apps.1200236.

Santos, D. (2017). Tanzania's Nature Reserves (30), 32. https:/ / www.cepf.net/sites/default/files/arc-journal-issue-30.pdf, downloaded 14 June 2018.

Saunders, R. M. K. (2012). The diversity and evolution of pollination systems in Annonaceae. Bot. J. Linn. Soc. 169: 222 - 244. https://doi.org/10.1111/j.10958339.2011.01208.x.

Schatz, G. E. (2002). Taxonomy and Herbaria in Service of Plant Conservation: Lessons from Madagascar's Endemic Families. Ann. Missouri Bot. Gard. 89: 145. https://doi.org/10.2307/ 3298559

Schneider, C. A., Rasband, W. S. \& Eliceiri, K. W. (2012). NIH Image to ImageJ: 25 years of image analysis. Nature Methods 9: 671 - 675 .

Setten, A. K. van, Koek-Noorman, J. \& Schipper, T. (1992). Fruits and seeds of Annonaceae. Biblioth. Bot. 142: 1 - 101. E. Schweizerbart'sche Verlagsbuchhandlung, Stuttgart. https:// www.schweizerbart.de/publications/detail/isbn/ 9783510480135/Bibliotheca_Botanica_Heft_142. Accessed 7 March 2018.

Shoo, R. A. \& Songorwa, A. N. (2013). Contribution of eco-tourism to nature conservation and improvement of livelihoods around Amani nature reserve, Tanzania. J. Ecotourism 12: 75 - 89. https://doi.org/ 10.1080/14724049.2013.818679.

Sprague, T. A. \& Hutchinson, J. (1916). African Annonaceae. Bull. Misc. Inform., Kew 1916: 145 - 161.

Systematics Association Committee for Descriptive Biological Terminology (1962). II. Terminology of simple symmetrical plane shapes (Chart 1). Taxon 11: 145 - 156. https://doi.org/10.2307/1216718.

Taberlet, P., Gielly, L., Pautou, G. \& Bouvet, J. (1991). Universal primers for amplification of three noncoding regions of chloroplast DNA. Pl. Molec. Biol. 17: 1105 - 1109. https://doi.org/10.1007/ BF00037152.

Turland, N. J., Wiersema, J. H., Barrie, F. R., Greuter, W., Hawksworth, D. L., Herendeen, P. S., Knapp, S., Kusber, W.-H., Li, D.-Z., Marhold, K., May, T. W., McNeill, J., Monro, A. M., Prado, J., Price, M. J. \& Smith, G. F. (eds) (2018). International Code of Nomenclature for algae, fungi, and plants (Shenzhen Code) adopted by the Nineteenth International Botanical Congress Shenzhen, China, July 2017. Regnum Veg. 159. Glashütten: Koeltz Botanical Books. 10.12705/ Code.2018

Turner, I. M. (2013). Verstreute Beobachtungen hinsichtlich der Familie Annonaceae by R. E. Fries: publication date and validity of new combinations. Kew Bull. 68: 365 - 367. https://doi.org/10.1007/ s12225-013-9453-1.

Verdcourt, B. (1986). New Taxa of East African Annonaceae. Kew Bull. 41: 287 - 297. https:// doi.org/10.2307/4102932.

Versteegh, C. P. C. \& Sosef, M. S. M. (2007). Revision of the African Genus Annickia (Annonaceae). Syst. Eै Geogr. Pl. 77: 91 - 118.

Walker, J. W. (1972). Contributions to the pollen morphology and phylogeny of the Annonaceae. II. Bot. J. Linn. Soc. 65: $173-178$.

Weberling, F. \& Hoppe, J. R. (1996). Comparative morphological evaluation of inflorescence characters in Annonaceae. Biosyst. Ecol. 10: 29 - 53.

White, F. (1979). The Guineo-Congolian Region and Its Relationships to Other Phytochoria. Bull.Jard. Bot. Natl. Belg. 49: 11 - 55. https://doi.org/10.2307/3667815.

WWF (n.d.). Angolan Scarp savanna and woodlands. World Wildlife Fund, Ecoregions. https:// www.worldwildlife.org/ecoregions/at1002. Accessed 8 June 2018

Zhou, L., Su, Y. C. F., Chalermglin, P. \& Saunders, R. M. K. (2010). Molecular phylogenetics of Uvaria (Annonaceae): relationships with Balonga, Dasoclema and Australian species of Melodorum. Bot. J. Linn. Soc. 163: 33 - 43. https://doi.org/10.1111/ j.1095-8339.2010.01045.x.

\section{Publisher's Note}

Springer Nature remains neutral with regard to jurisdictional claims in published maps and institutional affiliations. 